\title{
Using Stable Carbon Isotopes to Monitor for Potential Leakage of CO2 at an Enhanced Coal Bed Methane Recovery Site in Marshall County, WV
}

Bethany Meier

Follow this and additional works at: https://researchrepository.wvu.edu/etd

\section{Recommended Citation}

Meier, Bethany, "Using Stable Carbon Isotopes to Monitor for Potential Leakage of $\mathrm{CO} 2$ at an Enhanced Coal Bed Methane Recovery Site in Marshall County, WV" (2014). Graduate Theses, Dissertations, and Problem Reports. 6210.

https://researchrepository.wvu.edu/etd/6210

This Thesis is protected by copyright and/or related rights. It has been brought to you by the The Research Repository @ WVU with permission from the rights-holder(s). You are free to use this Thesis in any way that is permitted by the copyright and related rights legislation that applies to your use. For other uses you must obtain permission from the rights-holder(s) directly, unless additional rights are indicated by a Creative Commons license in the record and/ or on the work itself. This Thesis has been accepted for inclusion in WVU Graduate Theses, Dissertations, and Problem Reports collection by an authorized administrator of The Research Repository @ WVU. For more information, please contact researchrepository@mail.wvu.edu. 


\title{
Using Stable Carbon Isotopes to Monitor for Potential Leakage of $\mathrm{CO}_{2}$ at an Enhanced Coal
} Bed Methane Recovery Site in Marshall County, WV

\author{
Bethany Meier \\ Thesis Submitted to: \\ The Eberly College of Arts and Sciences \\ West Virginia University
}

In partial fulfillment of the requirements for the degree of

\author{
Master of Science in \\ Geology \\ Shikha Sharma, Ph.D (Chair) \\ Henry Rauch, Ph.D \\ Thomas Wilson, Ph.D \\ Department of Geology \& Geography \\ Morgantown, WV
}

2014

Keywords: Carbon, Isotopes, ECBM, Sequestration, Geochemistry

Copyright 2014 Bethany Meier 


\section{Abstract \\ USING STABLE CARBON ISOTOPES TO TRACK POTENITAL LEAKAGE OF $\mathrm{CO}_{2}$ AT AN ENHANCED COAL BED METHANE RECOVERY SITE IN MARSHALL COUNTY, WV}

\section{Bethany Meier}

Enhanced coal bed methane recovery, also known as ECBM, is a carbon capture and storage method in which carbon dioxide is injected into depleted gas formations (specifically unmineable coal beds) to aid in coal bed methane recovery for industrial uses. Produced natural gas, shallow groundwater, and soil vadose gas samples were collected at the CONSOL Energy Inc. $\mathrm{CO}_{2}$ Sequestration Pilot Test Site located in Marshall County, WV to test the feasibility using carbon isotope signatures to detect potential leakage of $\mathrm{CO}_{2}$ into overlying formations. $\mathrm{CO}_{2}$ was injected into the Upper Freeport coal seam at a depth of $396 \mathrm{~m}$ below valley bottom surface intermittently from September 2009 to December 2013. Water and gas samples were collected for isotopic analysis over a 12-month period (August 2013-August 2014). One set of water and gas samples collected in August 2013 was during an extended period of injection. The rest of the samples were collected during times the system was down or during the post-injection monitoring period that began in January 2014. The distinct carbon isotope signatures of the injected $\mathrm{CO}_{2}$, soil $\mathrm{CO}_{2}$, and coal bed $\mathrm{CO}_{2}$ allows us to use $\delta^{13} \mathrm{C}$ as a natural tracer to detect any potential leakage from the injection coal bed into the overlying coal bed, aquifers and shallow soil zone. The range of the carbon isotope values observed in each of the overlying systems (i.e. overlying Pittsburgh coal seam, groundwater aquifer and shallow soil) indicate carbon originated from natural sources and processes within individual systems. There appears to be no influence of the injected $\mathrm{CO}_{2}$ on the $\delta^{13} \mathrm{C}$ values of the overlying systems. The initial results indicate that there was no significant leakage of $\mathrm{CO}_{2}$ from the Upper Freeport coal seam to the overlying formations at the time of sampling. 


\section{Acknowledgements}

When I began Graduate School in the Fall of 2012, I knew it was going to be an amazing experience and that I would learn so much and grow from my time here. I want to sincerely thank Dr. Shikha Sharma for all of her continued support and guidance through this whole process. I would also like to thank Dr. Henry Rauch and Dr. Thomas Wilson, my committee members, for their support.

This work could not have been done without the funding provided by DOE-NETL, NSF, and NRCCE. I am very grateful for the support I received from J. Rodney Diehl, Dennis Stanko, and especially Brad Hega and Steve Henry (WVU) who were there to help me in the field from the day I began sampling the Marshall County site. I am appreciative of the laboratory support from the other students and staff in the WVU Stable Isotope Laboratory. An especially grateful thank you to James E. Locke, CONSOL Energy Inc's manager of field testing and operations for his help and permission for field site access.

I owe the most thanks to all of my friends and family for their support and continuous motivation. Without you, this thesis wouldn't have been possible. A final thank you to my biggest supporter, my husband Will, for your strength and encouragement over the last two and a half years. 


\section{Table of Contents}

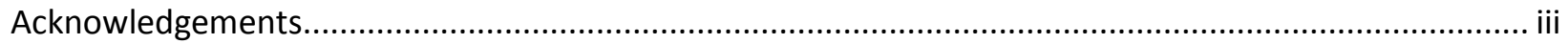

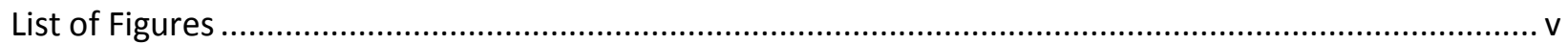

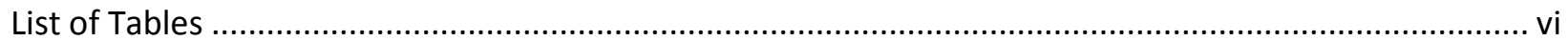

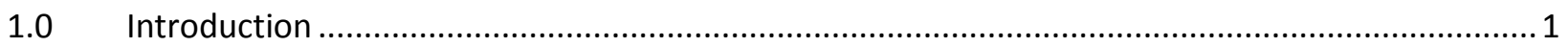

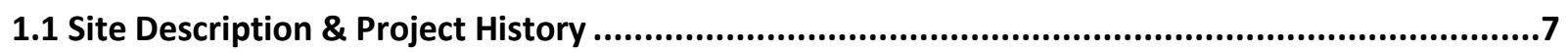

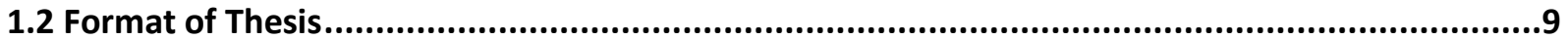

2.0 Using Stable Isotopes to Track Potential Leakage of $\mathrm{CO}_{2}$ at an Enhanced Coal Bed Methane

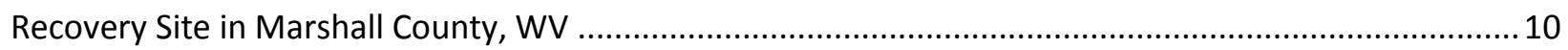

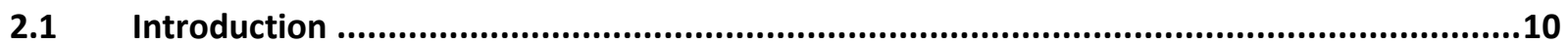

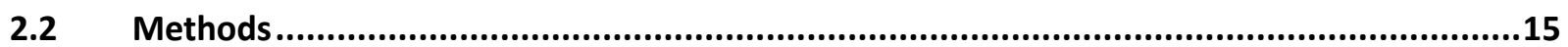

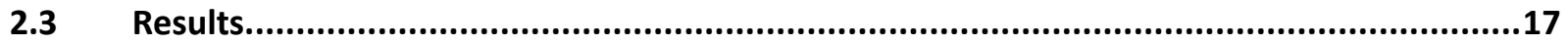

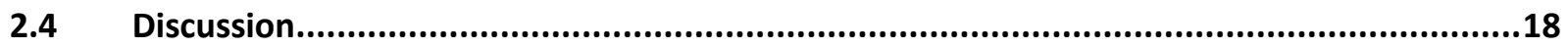

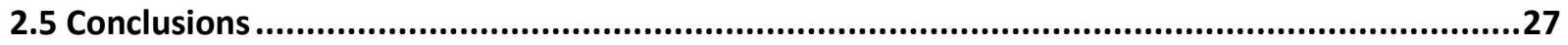

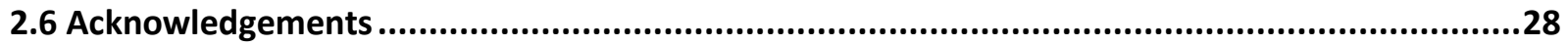

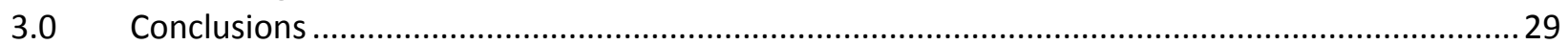

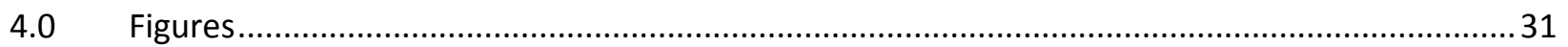

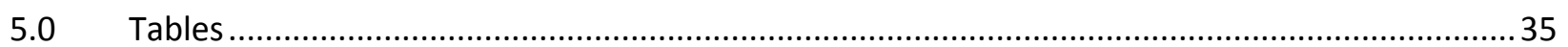

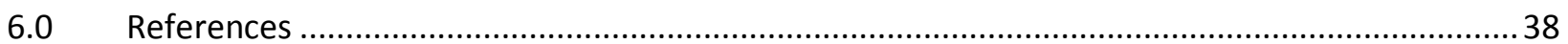




\section{List of Figures}

Figure 1. Location of the CONSOL Energy Carbon Sequestration Pilot Test Site in Marshall County, WV and geologic strip log of the site.

Figure 2. Timeline of the isotope sample collection at the Marshall County Site from August 2013-2014. The dark horizontal bars were times of active injection. The grey bar indicates the post-injection monitoring period. The tall vertical lines are dates of sampling for this study. The red line is 09/2013 when a high $\mathrm{CO}_{2} \%$ was recorded at a downstream Upper Freeport producing well, $\mathrm{MH}-11$.

Figure 3. Schematic cross sectional view of the Marshall County, WV site showing relative depths of both coal seams, shallow groundwater wells and soil vadose wells. The red wells in the center are $\mathrm{CO}_{2}$ Injection wells.

Figure 4. Comparison of the $\delta^{13} \mathrm{C}_{\mathrm{CO} 2}$ values of the distinct isotopic end members of the Marshall County site.

Figure 5. Monthly $\delta^{13} \mathrm{C}_{\mathrm{CO} 2}$ values of produced gas during the scheduled period of $\mathrm{CO}_{2}$ injection. The dark grey line indicates the $\delta^{13} \mathrm{C}_{\mathrm{CO} 2}$ of the injected $\mathrm{CO}_{2}$.

Figure 6. Monthly $\delta^{13} \mathrm{C}_{\mathrm{CO} 2}$ of soil vadose gas during the August 2013 to August 2014 sampling period. The dark grey line indicates the $\delta^{13} \mathrm{C}_{\mathrm{CO} 2}$ of the injected $\mathrm{CO}_{2}$.

Figure 7. Monthly $\delta^{13} C_{D I C}$ values of groundwater during the August 2013 to August 2014 sampling period. The red line indicates the $\delta^{13} C_{D I C}$ of the groundwater if the injected $\mathrm{CO}_{2}$ became the primary source of DIC. Groundwater samples were unable to be collected during January to March 2014 due to frozen wells.

Figure 8. Schematic of the $\delta^{13} \mathrm{C}$ values of different carbon sources, fractionation processes, and the expected enrichment factors that affect the carbon isotope signatures of different end-members at the study site. 


\section{List of Tables}

Table 1. A comparison of average $\delta^{13} \mathrm{C}$ values of the produced Pittsburgh $\mathrm{CO} 2$, shallow groundwater and soil vadose gas samples collected. .35

Table 2. A summary of the $\delta^{13} \mathrm{C}_{\mathrm{CH} 4}$ and the $\delta \mathrm{D}_{\mathrm{CH} 4}$ of the Pittsburgh and Upper Freeport coal seam produced natural gas collected during the injection of $\mathrm{CO}_{2}$ .36

Table 3. Summary of the $\delta^{13} \mathrm{C}$ values of the vegetation collected in May of 2014. .36 


\subsection{Introduction}

Carbon dioxide is a greenhouse gas within our atmosphere that absorbs and releases the heat from the sun and is responsible for keeping the Earth at a constant temperature (Geonet, 2008). $\mathrm{CO}_{2}$ is created through natural and anthropogenic processes including respiration, decay of organic matter and burning of fossil fuels. Humans are responsible for 32 Gigatonnes (Gt) of $\mathrm{CO}_{2}$ released into the atmosphere annually (Atlas, 2013). Scientists have been studying different methods of Carbon Capture and Storage (CCS), also known as carbon sequestration to reduce anthropogenic $\mathrm{CO}_{2}$ emissions and prevent drastic climate changes. The process of carbon sequestration involves taking industrially produced $\mathrm{CO}_{2}$ and injecting into suitable subsurface formations for long term storage (Geonet, 2008). Enhanced Coal Bed Methane recovery (ECBM) is a CCS process used to store $\mathrm{CO}_{2}$ in unmineable coal seams while simultaneously producing methane for industrial use. The North American Carbon Atlas Partnership estimated there is 61 to $119 \mathrm{Gt} \mathrm{CO}_{2}$ storage in the United States with a possible range of 310-450 megatonnes of $\mathrm{CO}_{2}$ storage in West Virginia (Atlas, 2013).

$\mathrm{CO}_{2}$ sequestration has been studied and practiced since the early 1970 's. There are many large and small-scale projects currently in progress to understand which geologic formations will be the most economically beneficial and have the best storage potential. Three options for storage include (1) Enhanced Oil Recovery (EOR) of depleted oil and gas fields, (2) Deep saline aquifers, and (3) ECBM of unmineable coal seams (Geonet, 2008; White et al., 2005). This project is focused on ECBM in an unmineable coal seam. 
Coal bed methane (CBM) is normally collected through the process of reservoir pressure depletion (Gale and Freund, 2001). ECBM is the process by which a gas is injected into a coal seam to increase the recovery of methane (White et al., 2005). During $\mathrm{ECBM}, \mathrm{CO}_{2}$ storage occurs in three ways. $\mathrm{CO}_{2}$ can become physically trapped in the cleats of the coal, dissolve into the water within the coal seam, or adsorb onto the surface of the coal (Mazzotti et al., 2009). The primary storage mechanism of $\mathrm{CO}_{2}$ is the adsorption onto the surface of the coal. $\mathrm{CO}_{2}$ will preferentially adsorb onto the coal surface and displace the methane that is already there. The current scientific assumption is that for every mol of methane desorbed, $2 \mathrm{~mol}$ of $\mathrm{CO}_{2}$ can be stored (Mazzotti et al., 2009; White et al., 2005). The displaced methane is then collected and can be used as an alternative energy source.

\section{Use of Stable Isotopes in Sequestration Studies}

Stable isotopes have been used in enhanced oil recovery sites to trace the movement and trapping of injected $\mathrm{CO}_{2}$ within oil field brines. At the Canadian Weyburn and Pembina oil fields in Saskatchewan and Alberta respectively, scientists have successfully used carbon isotopes to quantify the ionic trapping of $\mathrm{CO}_{2}$ (as bicarbonate) in the waters of carbonate and sandstone oil reservoirs (Emberley et al., 2004; Emberley et al., 2005; Johnson et al., 2011; Johnson et al., 2009; Raistrick et al., 2006) . More recently, geochemical and isotopic studies of artificial leakage of $\mathrm{CO}_{2}$ into shallow aquifers have been done at the ZERT research site in Bozeman, Montana and a site near Wittstock, Germany (Kharaka et al., 2010; Schulz et al., 2012). A study of $\mathrm{CO}_{2}$ injection into the Frio formation has also successfully used carbon isotopes to trace the movement of injected $\mathrm{CO}_{2}$ within deep saline aquifers (Kharaka et al., 2006). All of these studies have shown that stable carbon isotopes can be used as natural tracers to track $\mathrm{CO}_{2}$ as long as 
there is a significant difference in isotope values between the injected $\mathrm{CO}_{2}$ and the baseline values of the systems. We were interested in testing the use of stable carbon isotopes to track the injected $\mathrm{CO}_{2}$ plume and detect potential leakage into overlying geological formations, shallow aquifers and vadose soil at an enhanced coal bed methane recovery site in West Virginia.

Stable carbon isotope ratios can be used to distinguish natural sources of carbon within the vegetation, soil vadose zone, groundwater, and coal bed systems. Carbon isotope ratios are reported in permil (\%) relative to an international standard V-PDB (PeeDee Belemenite). Natural reactions, such as the dissolution of $\mathrm{CO}_{2}$ and photosynthesis, affect the amount of ${ }^{13} \mathrm{C}$ and ${ }^{12} \mathrm{C}$ isotopes in a system. These reactions result in different ratios of the carbon isotopes through fractionation and mixing processes. The different rates of fractionation and mixing result in distinct ranges of isotope ratios which can be used to understand what are the natural sources of carbon and the reactions occurring within the system. For example, the two major pathways of photosynthesis, C3 and C4 discriminate carbon isotopes differently and result in different isotope values. C3 plants preferentially use the lighter ${ }^{12} \mathrm{C}$, which result in $\delta^{13} \mathrm{C}$ values ranging from $-34 \%$ o to $-22 \%$. C4 plants are less likely to discriminate between ${ }^{12} \mathrm{C}$ and ${ }^{13} \mathrm{C}$ and therefore result in $\delta^{13} \mathrm{C}$ values ranging from -16\% to -10\%o (Vogel, 1993).

\section{Carbon Isotopic Composition of Plants and Soil $\mathrm{CO}_{2}$}

Carbon isotopes have previously been used to track leakage of $\mathrm{CO}_{2}$ from sequestration sites to the soil vadose zone in two artificial shallow $\mathrm{CO}_{2}$ injection projects, the ZERT site and the Wittstock site in Montana and Germany respectively (Fessenden et al., 2010; Kharaka et al., 2010; Peter et al., 2012; Schulz et al., 2012). Both projects have shown that changes in $\delta^{13} C_{\mathrm{co} 2}$ 
values of the soil vadose gas and near surface atmospheric $\mathrm{CO}_{2}$ can be used as a detector of leakage at a carbon sequestration site (Fessenden et al., 2010; Schulz et al., 2012).

The main source of $\mathrm{CO}_{2}$ in the soil is the type of vegetation growing on the sampling site, $\mathrm{C} 3, \mathrm{C} 4$ or CAM, each of which has different photosynthesis pathways. These plants fix atmospheric $\mathrm{CO}_{2}$ which has a $\delta^{13} \mathrm{C}$ value of approximately -8\%o (Keeling et al., 1979; Mook et al., 1983). The processes of diffusion and carboxylation during photosynthesis preferentially use lighter ${ }^{12} \mathrm{C}$. Hence, the plant organic matter tends to have depleted $\delta^{13} \mathrm{C}$ values. In a temperate climate region, such as West Virginia, most of the vegetation is comprised of C3 plants. The natural carbon isotope range of C3 plants is from $-34 \%$ to $-22 \%$ VPDB (Vogel, 1993). Changes in seasonal light, temperature, water stress, salinity and air pollution can result in variations in plant $\delta^{13} \mathrm{C}$ signatures (Farquhar et al., 1989; Farquhar et al., 1982) . Figure 8 is a diagram depicting the different processes that affect the $\delta^{13} \mathrm{C}$ values and the resulting ranges of $\delta^{13} \mathrm{C}$ of plants, soil $\mathrm{CO}_{2}$, and groundwater.

Soil $\mathrm{CO}_{2}$ is a product of root respiration and decomposition of organic matter. The decomposition of plant matter minimally fractionates the carbon isotopes. Soil $\mathrm{CO}_{2}$ that is found at depth has $\delta^{13} \mathrm{C}$ values similar to the $\delta^{13} \mathrm{C}$ of the vegetation. However, once $\mathrm{CO}_{2}$ is released into the soil through respiration the ${ }^{12} \mathrm{C}$ is preferentially diffuses out of the soil into the atmosphere (Amundson et al., 1998; Cerling et al., 1991). This causes the soil $\mathrm{CO}_{2}$ to be approximately 4-5\% more enriched than the $\delta^{13} \mathrm{C}$ of the plant organic matter from which it is derived (Boutton, 1991). If C3 vegetation having an average $\delta^{13} \mathrm{C}$ value of $-27 \%$, degrades, produces $\mathrm{CO}_{2}$, and lighter $\mathrm{CO}_{2}$ diffuses out, the soil $\mathrm{CO}_{2}$ will have a $\delta^{13} \mathrm{C}_{\mathrm{CO} 2}$ value of $-22 \%$. If rates of diffusion into the atmosphere are slower the $\delta^{13} C_{\mathrm{CO} 2}$ of soil will be $-27 \%$. 


\section{Carbon Isotopic Composition of Groundwater DIC (Dissolved Inorganic Carbon)}

All the groundwater collected in this study was analyzed for $\delta^{13} C_{D I C}$. The dissolved inorganic carbon (DIC) within groundwater is created by the dissolution of $\mathrm{CO}_{2}$ gas into the groundwater through the following series of reactions.
(1) $\mathrm{CO}_{2}(\mathrm{~g}) \rightarrow \mathrm{CO}_{2}(\mathrm{aq})$
$\mathrm{CO}_{2}$ diffusion into water
(2) $\mathrm{CO}_{2}$ (aq) $+\mathrm{H}_{2} \mathrm{O} \rightarrow \mathrm{H}_{2} \mathrm{CO}_{3}$ Hydration of $\mathrm{CO}_{2}$
(3) $\mathrm{H}_{2} \mathrm{CO}_{3} \rightarrow \mathrm{H}^{+}+\mathrm{HCO}_{3}^{-} \quad$ Disassociation of $\mathrm{H}_{2} \mathrm{CO}_{3}$
(4) $\mathrm{HCO}_{3}{ }^{-} \rightarrow \mathrm{H}^{+}+\mathrm{CO}_{3}{ }^{2-} \quad 2^{\text {nd }}$ disassociation of $\mathrm{H}_{2} \mathrm{CO}_{3}$

The highest prevailing carbon species is dependent on the $\mathrm{pH}$ of the system. In most natural systems ( $\mathrm{pH}$ of 6.5-8.5), the dominant carbon species is bicarbonate, $\mathrm{HCO}_{3}^{-}$(Drever, 1988) and reported natural $\delta^{13} C_{D I C}$ values of groundwater are normally within the range of $-11 \%$ to $-16 \%$ o V-PDB (Mook and de Vries, 2001).

Each step of the dissolution of $\mathrm{CO}_{2}$ has a specific fractionation (enrichment) factor. As the $\mathrm{CO}_{2}$ moves from one phase to another, the isotope value changes depending on the specific fractionation factor associated with the phase change. It should be noted the fractionation factor of the above reactions is dependent on the temperature of the system. The diffusion of $\mathrm{CO}_{2}$ has a small fractionation factor and has a small effect $\left(<1 \%\right.$ o on the $\delta^{13} \mathrm{C}$ of dissolved $\mathrm{CO}_{2}$. The largest fractionation $\left(\varepsilon=9.0 \%\right.$ at $\left.15^{\circ} \mathrm{C}\right)$ will occur during equations $2 \& 3$, the hydration of $\mathrm{CO}_{2}$ and creation of $\mathrm{HCO}_{3}{ }^{-}$(Mook et al., 1974). In a system starting with $\delta^{13} \mathrm{C}_{\mathrm{CO}}=-23 \%$, the $\delta^{13} C_{D I C}$ of the groundwater should be approximately $-15 \%$. Other factors that may affect the 
$\delta^{13} C_{D I C}$ value include possible influxes from different recharge sources or limestone and dolomite dissolution.

Carbon Isotopic Composition of Produced Natural Gas, Methane \& $\mathrm{CO}_{2}$

For this project two different coal seams were monitored, the Upper Freeport and the overlying Pittsburgh, at depths of $396 \mathrm{~m}$ and $213 \mathrm{~m}$ respectively. The isotopic composition of coal bed produced natural gas primarily depends on the origin of the gas and subsequent secondary processes such as substrate depletion, mixing and microbial oxidation (Whiticar et al., 1986). Natural gas produced from coal seams is composed primarily of methane and $\mathrm{CO}_{2}$ with small percentages of other gases and higher hydrocarbons such as $\mathrm{N}_{2}, \mathrm{O}_{2}$, ethane, etc (Clayton, 1998). There are three categories of methane found in nature: thermogenic, biogenic (or bacterial) and abiotic. These types of methane can be distinguished from each other by using both hydrogen and carbon isotope numbers. Thermogenic methane $\left(\delta^{13} C_{\mathrm{CH} 4}:-50\right.$ to $-20 \% ; \delta D_{\mathrm{CH} 4:-}$ 180 to $-130 \%$ ) is created by the thermal alteration of organic matter or thermal cracking of higher hydrocarbons and is generally found in higher rank coals at depths of greater than $1 \mathrm{~km}$ (Clayton, 1998; Rice, 1993; Schoell, 1980; Whiticar, 1999). Biogenic methane is created through two methanogenic processes: acetate fermentation $\left(\delta^{13} \mathrm{C}_{\mathrm{CH} 4}:-65\right.$ to $-50 \%$; $\delta \mathrm{D}_{\mathrm{CH} 4}:-400$ to $250 \%$ ) and $\mathrm{CO}_{2}$ reduction $\left(\delta^{13} \mathrm{C}_{\mathrm{CH} 4}:-110\right.$ to $-60 \%$; $\delta \mathrm{D}_{\mathrm{CH} 4}:-250$ to $-170 \%$ ) and is associated with coals less than $1 \mathrm{~km}$ in depth with little to no associated $\mathrm{C}_{2}+$ hydrocarbons (Whiticar, 1999; Whiticar et al., 1986).

Biogenic methane creation through $\mathrm{CO}_{2}$ reduction can also be associated with enriched $\delta^{13} \mathrm{C}_{\mathrm{CO} 2}$ values as a result of substrate depletion. Substrate depletion occurs when microbes use the 
lighter ${ }^{12} \mathrm{C}_{\mathrm{CO} 2}$ during bacterial methanogenesis, the ${ }^{13} \mathrm{C}_{\mathrm{CO} 2}$ accumulates in the gas substrate. If all of the lighter ${ }^{12} \mathrm{C}_{\mathrm{CO} 2}$ is used by the microbes in this reaction, then they will start using the enriched ${ }^{13} \mathrm{C}_{\mathrm{CO} 2}$ causing a shift towards more enriched $\delta^{13} \mathrm{C}_{\mathrm{CH} 4}$ values of methane as well.

Understanding the origin and processes that affect the $\delta^{13} \mathrm{C}$ values of vegetation, soil, groundwater and produced gases allows us to use carbon isotope ratios to distinguish between the natural $\mathrm{CO}_{2}$ sources and the injected $\mathrm{CO}_{2}$ as a source of carbon. It is possible to detect leakage from a sequestration system if the injected $\mathrm{CO}_{2}$ and the overlying formations being monitored are significantly different from one another.

\subsection{Site Description \& Project History}

The CONSOL Energy Carbon Sequestration Pilot Test site is located near Georgetown, WV on the eastern edge of the northern panhandle in Marshall County bordering Greene County, PA (Figure 1). Baseline geochemical monitoring by Dr. Rauch and his graduate student Brad Hega began in 2008. Injection began in 2009 and continued with some disruptions until 2013. Isotopic sampling began in 2012 and post injection monitoring has been approved until 2015 (Winschel et al., 2010). As of January 2014, approximately 5000 tons of $\mathrm{CO}_{2}$ had been injected into the Upper Freeport coal seam.

The site is approximately 200 acres in size and is bounded on all sides by underground horizontal methane production lines (Hega et al., 2011; Locke et al., 2011; Rauch et al., 2012; Winschel et al., 2010). There are five (5) CBM production wells, three (3) groundwater wells, and seven (7) soil vadose gas sampling wells that were sampled for this project. 
The production wells for this site were set up in a modified five spot pattern. There were three different locations of production wells drilled for this project on this site. $\mathrm{MH}-3$ \& $\mathrm{MH}-5$ are at the northern most drill location. $\mathrm{MH}-11$ \& MH-12 are located at the southernmost drill location. MH-18 \& MH-20 were originally production wells that were modified into injection wells and are located at the center of the site. The horizontals laterals of the $\mathrm{MH}-18$ well extend towards the north and west directions. The horizontal laterals of $\mathrm{MH}-20$ extend towards the south and east direction. The northern production wells, $\mathrm{MH}-5$ \& $\mathrm{MH}-3$, produce gas from the Upper Freeport and the Pittsburgh coal seams respectively. At the southern edge of the site area there are three production wells. $\mathrm{MH}-11$ \& $\mathrm{MH}-12$ are at one location and MC5-PG is located at a separate location nearby. $\mathrm{MH}-12$ and MC5-PG both produce from the Pittsburgh coal seam, while MH-11 produces from the Upper Freeport coal seam (Rauch et al., 2012; Winschel et al., 2010).

The groundwater and soil vadose locations are all located along the access road that runs through the middle of the test site. The groundwater wells, W-1, W-2, and W-3, are shown on Figure 1 as blue circles. As shown in the cross section (Figure 3), the groundwater samples are collected from the Washington formation within the Dunkard group located at a depth of approximately $30 \mathrm{~m}$ below the surface. The sampled soil vadose gas wells are located along the access road to the injection wells and $\mathrm{MH}-11$ and $\mathrm{MH}-12$. Soil gas wells $\mathrm{W}-1 \mathrm{~A}, \mathrm{~W}-2 \mathrm{~A}, \mathrm{~W}-2 \mathrm{D}$ and W-3A are located close to their counterpart groundwater wells. W-5 is the southern most of the soil vadose sampling wells. W-4 and W-7 are the furthest along the access road, west of the injection wells. All of the soil sampling wells collect gas from approximately 1-2 $\mathrm{m}$ below the surface (Winschel et al., 2010). 
The geology in the area of the Marshall County test site is a relatively simple sedimentary sequence with clastic sedimentary rocks, limestones and coals (Ruppert and Rice, 2001). A general geologic strip log of the site can be found in Figure 1. This project focuses on two coal seams, the younger Pittsburgh coal seam and the older Upper Freeport coal seam. $\mathrm{CO}_{2}$ was injected into the Upper Freeport coal seam. The Pittsburgh coal is the oldest formation within the Pennsylvanian age Monongahela group. At the Marshall county site it is at a depth of approximately $213 \mathrm{~m}$ below the valley bottom surface (Ruppert et al., 2002; Winschel et al., 2010). The Upper Freeport coal is the youngest formation within the Pennsylvanian age Allegheny group. The coal seam depth is reported to be approximately $396 \mathrm{~m}$ below the valley bottom surface at the test site (Locke et al., 2011; Ruppert and Rice, 2001; Winschel et al., 2010).

The dip of the rocks in the region is $\sim 2-3^{0}$ to the S/E. The Washington Anticline is to the northwest of the site area and there are no major faults running through the injection study area. (Wilson et al., 2009).

\subsection{Format of Thesis}

Chapter 1 of this paper contains the background information and literature review done in preparation of this study and manuscript. Chapter 2 is a manuscript of this thesis for potential submissions to a scientific journal. Chapter 3 is a summary of the final conclusions of this thesis. 


\title{
2.0 Using Stable Isotopes to Track Potential Leakage of $\mathrm{CO}_{2}$ at an Enhanced Coal Bed Methane Recovery Site in Marshall County, WV
}

\begin{abstract}
Produced natural gas, shallow groundwater, and soil vadose gas samples were collected at the CONSOL Energy Inc. $\mathrm{CO}_{2}$ Sequestration Pilot Test Site in Marshall County, WV to test the feasibility of using carbon isotope signatures to detect potential leakage of $\mathrm{CO}_{2} . \mathrm{CO}_{2}$ was injected into the Upper Freeport coal seam at a depth of $396 \mathrm{~m}$ intermittently from September 2009 to December 2013. Water and gas samples were collected over a 12 month period (August 2013-August 2014). The injected $\mathrm{CO}_{2}$ had a $\delta^{13} \mathrm{C}$ value ranging from $-12.0 \%$ o to $11.0 \%$ V-PDB. The average $\delta^{13} \mathrm{C}_{\mathrm{CO} 2}$ values of the soil vadose gas, the groundwater wells, and the $\mathrm{CO}_{2}$ in the gas produced from the overlying Pittsburgh coal seam were $-25.0 \%,-16.6 \%$ and $+22.8 \%$ o -PDB respectively. These distinct carbon isotope signatures allow us to use $\delta^{13} \mathrm{C}$ as a natural tracer to detect any potential leakage from the injection coal bed into the overlying coal bed, aquifers and shallow soil zone. The range of the carbon isotope values observed in each of the overlying systems indicate carbon originated from natural sources and processes within individual systems and that there was no significant leakage of $\mathrm{CO}_{2}$ from the Upper Freeport coal to the overlying formations.
\end{abstract}

\subsection{Introduction}

Carbon Capture and Storage (CCS) has been a rapidly developing field of research in which new MVA (monitoring, verifying and accounting) techniques are being developed to quantify the amount of $\mathrm{CO}_{2}$ stored within a geologic formation, as well as to monitor for potential leakage to the surface. Humans are responsible for releasing approximately 32 Gigatonnes of $\mathrm{CO}_{2}$ into the atmosphere annually through processes such as the burning of fossil fuels (Atlas, 2013). Potential reservoirs for the storage of this excess $\mathrm{CO}_{2}$ through CCS include both conventional and unconventional reservoirs such as depleted oil and gas fields, deep saline aquifers and unmineable coal seams (White et al., 2005). This study is focused on an Enhanced Coal Bed Methane recovery site, in which $\mathrm{CO}_{2}$ is injected into unmineable coal seams and adsorbs onto 
the surface of the coal while displacing coal bed methane and simultaneously increasing the production of methane for industrial use (Mazzotti et al., 2009).

Extensive research at active CCS sites such as the Weyburn Oil Field in Saskatchewan, Canada has shown that monitoring geochemical parameters such as $\mathrm{pH}$, alkalinity, major cations, and major anions and $\delta^{13} C_{D I C}$ of produced fluids at active injection sites allows for the tracking of a $\mathrm{CO}_{2}$ plume within a system and can indicate storage through processes such as the dissolution of the injected $\mathrm{CO}_{2}$ and subsequent ionic trapping of $\mathrm{HCO}_{3}{ }^{-}$(Emberley et al., 2004; Emberley et al., 2005; Raistrick et al., 2006).

More recently, researchers have investigated the potential of using geochemical and isotopic data to monitor $\mathrm{CO}_{2}$ plumes and detect any leakage from the CCS reservoirs. Leakage from the CCS systems can occur through various natural and anthropogenically created pathways including, but not limited to, faults and cracked well casings or boreholes. Laboratory experiments, natural analogs, and artificial shallow leakage systems have been studied to understand the effects the leakage of $\mathrm{CO}_{2}$ can have on systems such as shallow groundwater or soil vadose zones and to develop new monitoring techniques (Fessenden et al., 2010; Kharaka et al., 2010; Schulz et al., 2012). These artificial leakage sites have shown that after $\mathrm{CO}_{2}$ is injected into a shallow groundwater aquifer there is a subsequent decrease in $\mathrm{pH}$ and increase in alkalinity and electrical conductivity (Schulz et al., 2012).

Carbon isotope ratios have been successfully used in multiple MVA experiments for tracing the movement and ionic trapping of injected $\mathrm{CO}_{2}$ (as bicarbonate) in the waters of carbonate and sandstone reservoirs at the Pembina and Weyburn oil fields, tracing the movement of injected 
$\mathrm{CO}_{2}$ within a deep saline aquifer (Frio Formation), and have been used to trace leakage from artificial injection sites into overlying groundwater and the shallow soil vadose zone in Montana and Germany (Clark and Fritz, 1997; Emberley et al., 2004; Emberley et al., 2005; Fessenden et al., 2010; Johnson et al., 2011; Johnson et al., 2009; Kharaka et al., 2006; Kharaka et al., 2010; Peter et al., 2012; Raistrick et al., 2006; Schulz et al., 2012).

The purpose of this study was to test the applicability of using carbon stable isotopes to monitor for potential leakage at the CONSOL Pilot carbon sequestration test site in Marshall County, West Virginia. Samples of the isotopic end-members (the injected $\mathrm{CO}_{2}$, the overlying Pittsburgh coal seam, shallow groundwater and soil vadose gas) were collected at the site during and after $\mathrm{CO}_{2}$ injection. The isotopic variations observed in the different end-members were analyzed and interpreted keeping in perspective the fractionation processes that cause the natural variations in these systems. Monitoring for abnormal isotopic shifts in the $\delta^{13} \mathrm{C}$ of the samples could indicate significant leakage from the coal bed in which $\mathrm{CO}_{2}$ was injected.

\section{Study Area}

The CONSOL Energy Carbon Sequestration Pilot Test Site is located near Georgetown, WV on the eastern edge of the northern WV panhandle in Marshall County bordering Greene County, PA (Figure 1). The study site was set up to determine if there is leakage of $\mathrm{CO}_{2}$ to the surface during the injection period in an ECBM recovery system. Baseline geochemical monitoring began in 2008. Injection began in 2009 and continued with some disruptions until 2013. Periodic isotopic sampling began in 2012. Sampling for this study began in August of 2013 during an extended period of ongoing injection and continued through August 2014 (Figure 2). 
In September of 2013, a high $\mathrm{CO}_{2} \%$ was recorded at a downstream Upper Freeport well and injection was discontinued for an investigation of the cause of the high $\mathrm{CO}_{2} \%$. Injection resumed in October 2013 until early November 2013 due to a pump failure. The injection system was offline until the end of December 2013. In January 2014, the scheduled postinjection monitoring period began and will continue through December of 2015 (Winschel et al., 2010).

The site is approximately $1 \mathrm{~km}^{2}$ in size and is bounded on all sides by underground horizontal methane production lines. There were five (5) CBM production wells, three (3) groundwater wells, and seven (7) soil vadose gas sampling locations for carbon isotopes during this study (Hega et al., 2011; Locke et al., 2011; Rauch et al., 2012; Winschel et al., 2010).

The production wells for this site were set up in a modified five spot pattern. There were three different locations of production wells drilled for this project on this site. $\mathrm{MH}-3$ \& $\mathrm{MH}-5$ are at the northern most drill location. $\mathrm{MH}-11$ \& $\mathrm{MH}-12$ are located at the southernmost drill location (Figure 1). $\mathrm{MH}-18$ \& $\mathrm{MH}-20$ were originally production wells that were modified into injection wells and are located at the center of the site. The horizontals laterals of the $\mathrm{MH}-18$ well extend towards the north and west directions. The horizontal laterals of $\mathrm{MH}-20$ extend towards south and east direction (Rauch et al., 2012; Winschel et al., 2010). The northern production wells, $\mathrm{MH}-5$ \& $\mathrm{MH}-3$, produce gas from the Upper Freeport and the Pittsburgh coal seams respectively.

At the southern edge of the site area there are three production wells. $\mathrm{MH}-11$ \& $\mathrm{MH}-12$ are located together with MC5-PG nearby. MH-12 and MC5-PG both produce from the Pittsburgh 
coal seam, while $\mathrm{MH}-11$ produces from the Upper Freeport. The groundwater and soil vadose gas sampling locations are all located along the access road that runs through the middle of the test site. The groundwater wells, W-1, W-2, and W-3, are shown on Figure 1 as blue circles. As shown in the cross section (Figure 3), the groundwater samples are collected from the Washington formation within the Dunkard group located at a depth of approximately $30 \mathrm{~m}$ below the surface. The soil vadose wells $\mathrm{W}-1 \mathrm{~A}, \mathrm{~W}-2 \mathrm{~A}, \mathrm{~W}-2 \mathrm{D}$ and $\mathrm{W}-3 \mathrm{~A}$ are located close to their counterpart groundwater wells; W-5 is the southern most of the soil vadose sampling wells; and $W-4$ and $W-7$ are the furthest along the access road, west of the injection wells. All of the soil sampling wells collect gas from approximately 1-2 m below the surface (Winschel et al., 2010).

The geology in the area of the Marshall County test site is a relatively simple sedimentary sequence with clastic sedimentary rocks, limestones and coals (Figure 1). This project focuses on two coal seams, the younger Pittsburgh coal seam and the older Upper Freeport coal seam. The Pittsburgh coal is the oldest formation within the Pennsylvanian age Monongahela group. At the Marshall county site it is at a depth of approximately $213 \mathrm{~m}$ below the valley bottom land surface. The Upper Freeport coal is the youngest formation within the Pennsylvanian age Allegheny group. This coal seam depth is reported to be approximately $396 \mathrm{~m}$ below the valley bottom land surface at the test site. $\mathrm{CO}_{2}$ was injected into the Upper Freeport coal seam (Locke et al., 2011; Ruppert and Rice, 2001; Ruppert et al., 2002; Winschel et al., 2010).

The dip of the rocks in the region is $\sim 2-3^{0}$ to the S/E. The Washington Anticline is to the northwest of the site area and there are no major faults reported running through the injection study area (Wilson et al., 2009). 


\subsection{Methods}

Sampling for this project took place over a 12-month period from August 2013 to August 2014.

The three (3) groundwater and seven (7) soil gas samples were collected monthly when possible. Produced gas from the Pittsburgh coal seam was collected quarterly. Injected $\mathrm{CO}_{2}$ was analyzed three times during the injection period to prove consistency. In May 2014, vegetation samples were collected for $\delta^{13} \mathrm{C}$ analysis. During a sampling trip all of the samples listed above were collected on the same day, before noon. One set of samples (soil vadose, groundwater and produced gas- Aug 2013) were collected during an extended period of injection. The other remaining samples were collected during times when the system was down or during the post injection-monitoring phase of the project (Figure 2). Field parameters such as $\mathrm{pH}$ and temperature and other geochemical parameters such as cations and anions were collected by Dr. Rauch's research group at WVU.

During the fieldwork in May 2014 samples of plant matter, leaves, and grasses were collected within a 5-foot radius around the soil vadose wells. There were a total of 7 vegetation samples: W1A, W2A, W2D, W3A, W4, W5, and W7, all named to the corresponding nearby soil vadose wells.

Soil vadose gas samples were collected from a vadose well casing port on an in-situ device constructed of PVC pipe that was connected to a piece of rubber tubing that reached a screened interval from approximately 1-1.5 m. Gas bench sampling vials (15 mL) filled with He were attached to a needle on a sampling port via a rubber septa and allowed to equilibrate for 30 minutes with diffused soil vadose gas. 
Groundwater samples for $\delta^{13} C_{D I C}$ were collected through an in-situ pumping system created by Dr. Rauch's research group at WVU. The samples were collected after two casing volumes of water were expelled when possible. The samples were filtered through a Cameo 45 (micron) pre-filter into a $10 \mathrm{~mL}$ Wheaton serum vial with no headspace. Prior to the injection of the water sample, 1-2 drops of benzalkonium chloride were added to the Wheaton vial to prevent any metabolic activity.

$\delta^{13} \mathrm{C}_{\mathrm{CO} 2}$ and $\delta^{13} \mathrm{C}_{\mathrm{DIC}}$ samples and duplicates were analyzed on a Finnigan Delta Advantage continuous flow isotope ratio mass spectrometer (CF-IRMS) with a ThermoQuest Finnigan GasBench II device. The produced gas and injected $\mathrm{CO}_{2}$ samples were sent to Isotech Laboratories for isotope and gas composition analysis. The $\delta^{13} \mathrm{C}_{\mathrm{CO} 2}$ analysis completed on the produced gas and injected $\mathrm{CO}_{2}$ at Isotech Laboratories, Inc was done on a Finnigan Delta Plus XL Isotope Ratio Mass Spectrometer. Gas composition was measured using a Shimadzu 2010 GC system and the concentrations of gas were calculated by use of Henry's Law. Duplicate samples of $\delta^{13} \mathrm{C}_{\mathrm{CO} 2}$ and gas composition analysis were run on a Thermo Scientific GC-Isolink coupled to a Finnigan Delta Advantage Isotope Ratio Mass Spectrometer through a Low Flow outlet of the Conflo IV device and Allegiant MicroGC systems respectively at the WVUSIL.

The vegetation analyzed for $\delta^{13} \mathrm{C}$ was transported back to the WVUSIL and placed in an oven at $30^{\circ} \mathrm{C}$ until dried out. The samples were then ground and homogenized with a mortar and pestle. A $1 \mathrm{mg}$ sample was placed in a tin capsule and sealed. A Costech ECS 4010 Elemental Analyzer connected to a Delta V Advantage IRMS through a Conflo IV device was used to analyze the plant samples. 


\subsection{Results}

Results of all the isotopic analyses of the vegetation, shallow soils, vadose gas, shallow groundwater, injected CO2, and produced gas are in Table 1. Stable isotope ratios for $\delta^{13} \mathrm{C}_{\mathrm{CO} 2}$ and $\delta^{13} C_{D I C}$ are reported in per mil (\%) relative to V-PDB (Pee Dee Belemenite). The $\mathrm{CO}_{2}$ that was injected into the Upper Freeport coal bed during this experiment had $\delta^{13} C_{\mathrm{cO} 2}$ values that ranged from -11.0 to $-12.1 \%$ over the sampling period.

The produced gas from the Pittsburgh coal bed was composed of 89.6-96.4\% methane with a small percentage of $\mathrm{CO}_{2}(1.74-3.83 \%)$. The $\delta^{13} \mathrm{C}_{\mathrm{CH} 4}$ values of the Pittsburgh coal seam produced gases range from $-48.8 \%$ o to $-47.5 \%$ ond $\delta D_{\mathrm{CH}_{4}}$ values range from $-195.7 \%$ o to $-189.9 \%$ (Table 2). The $\delta^{13} \mathrm{C}_{\mathrm{CO} 2}$ of the produced gases were consistently enriched values that range from $+19.1 \%$ to $+25.4 \%$ as seen in Figure 5 .

In general, the produced gas from the Upper Freeport Coal seam was composed of $89.6 \%$ 95.9\% methane with very low $\mathrm{CO}_{2} \%(<0.3 \%)$. The $\delta^{13} \mathrm{C}_{\mathrm{CH} 4}$ of the Upper Freeport gases range from $-43.3 \%$ o to $-42.3 \%$ and the $\delta \mathrm{D}$ values range from $-176.9 \%$ o to $-173.9 \%$ (Table 2 ). When the $\mathrm{CO}_{2}$ percentage is less than $0.5 \%$, the instrument cannot measure $\delta^{13} \mathrm{C}_{\mathrm{CO} 2}$. However, when the analysis has been successful of the $\mathrm{CO}_{2}$ in the produced gas, the $\delta^{13} \mathrm{C}_{\mathrm{CO} 2}$ was $-11 \%$, which is comparable with the injected $\mathrm{CO}_{2}$.

Vegetation samples including a mixture of leaves, grasses and other plants were collected at each soil gas well in May of 2014 to understand the $\delta^{13} \mathrm{C}$ of the source of the soil $\mathrm{CO}_{2}$. The vegetation had a $\delta^{13} \mathrm{C}$ range from $-31.2 \%$ to $-25.6 \%$ o -PDB with a single outlier (W-4) that had a $\delta^{13} \mathrm{C}$ value of $-17.0 \%$ (Table 3 ). With the exception of $\mathrm{W}-4$, the $\delta^{13} \mathrm{C}$ values fall within the 
expected range of C3 plants (-34\% to $-22 \%$ ), which are the dominant vegetation in temperate climates such as West Virginia (Vogel, 1993).

The soil vadose $\delta^{13} C_{\mathrm{CO} 2}$ values ranged from $-29.2 \%$ to $-21.0 \%$ with an average value of approximately $-25.0 \%$ over the year of sampling (Table 1 ). The variations in $\delta^{13} \mathrm{C}_{\mathrm{CO} 2}$ of each of the wells over the year of sampling can be seen in Figure 6. The soil vadose samples are well within the expected range for a site dominated with C3 vegetation, $-34 \%$ o to $-20 \%$ (Boutton, 1991; Vogel, 1993).

The $\delta^{13} C_{D I C}$ values of the three groundwater wells were consistent over the time of sampling as seen in Figure 7. The $\mathrm{pH}$ of the ground waters was between 8.06 and 9.29 and the temperatures were between $11.0-14.6^{\circ} \mathrm{C}$. A summary of the $\delta^{13} \mathrm{C}_{\mathrm{DIC}}$ values can be found in Table 1. W-1 had an average value of $-16.4 \%$ and had the largest range in values, $-18.2 \%$ o to $-15.8 \%$ o. W-2 had the most constant $\delta^{13} C_{D I C}$ values with an average $\delta^{13} C_{D I C}$ value of $-16.6 \%$ and a range from $-16.9 \%$ o to $-16.3 \%$. W-3 had an average $\delta^{13} C_{D I C}$ value of $-16.8 \%$ ond a range from $-17.9 \%$ o to $-16.1 \%$. Groundwater samples were not collected in January through March of 2014 due to the wells being frozen.

\subsection{Discussion}

At the Marshall County site, there are four distinct carbon end-members whose isotopic signatures are depicted in Figure 4. The isotopic composition of $\mathrm{CO}_{2}$ injected into the Upper Freeport coal seam is distinct from other natural sources of $\mathrm{CO}_{2}$ at the study site. The injected $\mathrm{CO}_{2}$ was transported in from an ethanol plant, which ferments corn to create ethanol. The 
injected $\mathrm{CO}_{2}$ had a constant and distinct average $\delta^{13} \mathrm{C}_{\mathrm{CO} 2}$ value of $-11.4 \%$. This value is within the expected $\delta^{13} \mathrm{C}$ values of C4 plants (corn) that range from -10\% to -16\% (Vogel, 1993).

\section{Produced Gas}

The two coal seams being monitored at this site are the Upper Freeport and the overlying Pittsburgh at depths of $396 \mathrm{~m}$ and $213 \mathrm{~m}$ respectively under the valley bottom surface. Both the Upper Freeport and Pittsburgh are medium ash and medium sulfur coals. The ranking of the Upper Freeport changes across the Appalachian basin, from low volatile bituminous in the western portion of the basin to high volatile $\mathrm{C}$ bituminous in the eastern portion of the basin. The Pittsburgh is a high volatile A bituminous ranked coal (Ruppert et al., 2002).

The molecular and isotopic composition of coal bed produced natural gas primarily depends on the origin of the gas. The produced gases from the wells at the Marshall County site were predominantly methane (89.6-96.4\%) with a small percentage of $\mathrm{CO}_{2}(\sim 2-3 \%)$. There are three different types of methane found in nature: thermogenic methane, biogenic (or bacterial) methane and abiotic methane and each of these have unique $\delta^{13} \mathrm{C}_{\mathrm{CH} 4}$ and $\delta \mathrm{D}_{\mathrm{CH} 4}$ signatures and molecular composition. Thermogenic methane $\left(\delta^{13} C_{\mathrm{CH}_{4}:-50}\right.$ to $-20 \%$; $\delta D_{\mathrm{CH}_{4}:}-180$ to $-130 \%$ ) is found in higher rank coals at depths greater than $1 \mathrm{~km}$ and is normally associated with $>4 \% \mathrm{C}_{2}+$ hydrocarbons (Clayton, 1998; Schoell, 1980; Whiticar, 1999). Biogenic methane is created through two methanogenic processes: acetate fermentation $\left(\delta^{13} C_{\mathrm{CH}_{4}}:-65\right.$ to $-50 \%$; $\delta \mathrm{D}_{\mathrm{CH} 4}:-400$ to $-250 \%$ o) and $\mathrm{CO}_{2}$ reduction $\left(\delta^{13} \mathrm{C}_{\mathrm{CH} 4}:-110\right.$ to $-60 \%$; $\delta \mathrm{D}_{\mathrm{CH} 4}$ : -250 to $-170 \%$ ). Biogenic methane is associated with shallower depth coals and small percentages of $\mathrm{C}_{2}+$ hydrocarbons (Whiticar, 1999; Whiticar et al., 1986). 
The $\delta^{13} \mathrm{C}_{\mathrm{CH} 4}\left(-43.3\right.$ to $-42.3 \%$ ) and $\delta \mathrm{D}_{\mathrm{CH} 4}(-176.9$ to $-173.9 \%$ ) isotope values of the Upper Freeport coal seam produced gas suggested that the methane is thermogenic in origin. This conclusion is supported by the fact that the Upper Freeport is at a depth of $396 \mathrm{~m}$ and has a higher percentage of $\mathrm{C}_{2}{ }^{+}$hydrocarbons ( $\left.2.7 \%\right)$.

The Upper Freeport coal seam had extremely low $\mathrm{CO}_{2} \%$ values ( 0.1 to $0.3 \%$ ) for all samples except the September 2013 sample of $\mathrm{MH}-11$ and in August 2014. The low $\mathrm{CO}_{2}$ percentages made it impossible to analyze the samples for $\delta^{13} C_{\text {coz. }}$. In September of 2013, however, there was a high percentage of $\mathrm{CO}_{2}$ recorded at the downstream Upper Freeport well, $\mathrm{MH}-11$ (Figure 3). When the gas was analyzed, the $\delta^{13} \mathrm{C}_{\mathrm{CO} 2}$ value was $-11 \%$. This allowed us to conclude that the plume of injected $\mathrm{CO}_{2}$ had reached $\mathrm{MH}-11$. Another produced gas sample collected the end of the monitoring period in August 2014 also showed $\delta^{13} \mathrm{C}_{\mathrm{CO} 2}$ value of $-11.6 \%$ further supporting that the plume of injected $\mathrm{CO}_{2}$ had reached the downstream monitoring well of the Upper Freeport coal seam in which $\mathrm{CO}_{2}$ was injected.

The Pittsburgh coal seam $\mathrm{CH}_{4}$ isotope values $\left(\delta^{13} \mathrm{C}_{\mathrm{CH} 4}\right.$ : -43.3 to $-42.3 \%$; $\delta \mathrm{D}_{\mathrm{CH} 4}$ : -176.9 to $173.9 \%$ ) are indicative of methane that is thermogenic in origin. However, the Pittsburgh coal seam is at $213 \mathrm{~m}$ depth, the $\mathrm{C}_{2}{ }^{+} \%$ values are very small (0.2-0.7\%) and a greater percentage of $\mathrm{CO}_{2}(2-3 \%)$ is present in the sample. These parameters indicate a probable biogenic origin of the $\mathrm{CH}_{4}$ in the Pittsburgh coal seam (Rice, 1993). The highly enriched $\delta^{13} \mathrm{C}_{\mathrm{CO}}$ values $(+19.1$ to $25.4 \%$ ) of the Pittsburgh coal seam gases are indicative of $\mathrm{CO}_{2}$ reduction by microbes. One reason that the Pittsburgh coal seam produced methane could mimic thermogenic methane isotope values is due to substrate depletion. During the bacterial methanogenesis reaction the lighter ${ }^{12} \mathrm{C}_{\mathrm{CO} 2}$ is preferentially used by microbes and the ${ }^{13} \mathrm{C}_{\mathrm{CO} 2}$ accumulates in the substrate, 
enriching the $\delta^{13} \mathrm{C}_{\mathrm{CO} 2}$ value of the gas substrate. If most or all of the lighter ${ }^{12} \mathrm{C}_{\mathrm{CO} 2}$ is used by the microbes in the $\mathrm{CO}_{2}$ reduction reaction, then the microbes will have to start using the heavier/more enriched ${ }^{13} \mathrm{C}$ to create methane. If this happens, then the final $\delta^{13} \mathrm{C}_{\mathrm{CH} 4}$ value of the methane will continue to become more enriched causing bacterial origin methane to mirror $\delta^{13} \mathrm{C}_{\mathrm{CH} 4}$ values that look like thermogenic methane.

There is a significant distinction between the enriched $\delta^{13} C_{\mathrm{CO} 2}$ values of Pittsburgh coal seam $(+23.1 \%$ o $)$ and the depleted value of the injected $\mathrm{CO}_{2}(-11.4 \%)$, which can be seen on Figures 5 . If significant leakage of $\mathrm{CO}_{2}$ were to occur from the Upper Freeport coal seam, the overlying Pittsburgh coal seam would be the first of the monitored zones affected, as it is $183 \mathrm{~m}$ above the Upper Freeport coal seam. The large difference in isotope values between the Pittsburgh coal seam and the injected carbon dioxide means that the $\delta^{13} \mathrm{C}_{\mathrm{CO} 2}$ of the Pittsburgh coal seam would drastically shift if the sampled $\mathrm{CO}_{2}$ mixed with the injected $\mathrm{CO}_{2}$. If mixing were to occur, the following formula of a simple linear two end-member mixing model could be used to predict the amount of injected $\mathrm{CO}_{2}$ influencing the $\delta^{13} \mathrm{C}_{\mathrm{CO} 2}$ value: $\delta_{\text {sample }}=\left(\delta_{1}\right)\left(f_{1}\right)+\left(\delta_{P}\right)\left(f_{P}\right)$ where $\delta_{P}$ and $\delta_{l}$ are the known $\delta^{13} \mathrm{C}_{\mathrm{CO} 2}$ value of the Pittsburgh coal seam $\mathrm{CO}_{2}$ and the injected $\mathrm{CO}_{2}$ respectively and the $f_{P}$ and $f_{l}$ are the fraction of Pittsburgh coal seam $\mathrm{CO}_{2}$ and injected $\mathrm{CO}_{2}$ in the sample mix .

The hypothetical two end-member mixing model calculation above was used to show the expected change in $\delta^{13} C_{\mathrm{CO} 2}$ if leakage were to occur at MC-5PG, a Pittsburgh coal seam gas producing well. By knowing the natural $\delta^{13} \mathrm{C}_{\mathrm{CO} 2}$ for the Pittsburgh $\mathrm{CO}_{2}$, it is possible to use the equation listed above to calculate what percent contribution of the injected $\mathrm{CO}_{2}$ at each well that would change the $\delta^{13} \mathrm{C}_{\mathrm{CO} 2}$ value enough to indicate leakage. Based on this mixing model 
and the $\delta^{13} \mathrm{C}_{\mathrm{CO} 2}$ values of the Pittsburgh produced gas collected, at least a $1.5 \%$ contribution of the injected $\mathrm{CO}_{2}$ would shift the $\delta^{13} \mathrm{C}_{\mathrm{CO} 2}$ values significantly enough to indicate potential leakage.

The $\delta^{13} \mathrm{C}_{\mathrm{CO} 2}$ values of the produced gas samples, collected from downstream monitoring wells in September 2013 and August 2014, clearly indicated the $\mathrm{CO}_{2}$ plume had travelled over the entire study site and reached the downstream Upper Freeport coal seam producing well $\mathrm{MH}-$ 11. However, the $\delta^{13} \mathrm{C}_{\mathrm{CO} 2}$ values of the produced gas samples collected from the three overlying Pittsburgh coal seam wells did not change and remained consistently enriched during the entire sampling period indicating there is no evidence of leakage of $\mathrm{CO}_{2}$ from the underlying Upper Freeport coal seam into which $\mathrm{CO}_{2}$ was injected (Figure 5).

Vegetation and Soil $\mathrm{CO}_{2}$

The primary source of $\mathrm{CO}_{2}$ within a soil system is the type of vegetation present in the system, C3, C4 or CAM. In a temperate climate region such as West Virginia, most of the vegetation is comprised of $\mathrm{C} 3$ plants. Plants fix atmospheric $\mathrm{CO}_{2}\left(\delta^{13} \mathrm{C} \sim-8 \%\right.$ ) and preferentially use lighter ${ }^{12} \mathrm{C}$ during photosynthesis resulting in $\delta^{13} \mathrm{C}$ of plant matter having depleted $\delta^{13} \mathrm{C}$ values ranging between $-34 \%$ o to $-22 \%$ (Keeling et al., 1979; Mook et al., 1983; Vogel, 1993). The $\delta^{13} \mathrm{C}$ of the plants at the Marshall County site ranged from $-31.2 \%$ o to $-25.6 \%$, which is within the reported natural carbon isotope range of C3 plants, $-34 \%$ o to $-22 \%$ (Vogel, 1993) and values that previous studies reported for C3 plants (-30\% to -22\%o), with the exception of a single well, W4 (Lowdon and Dyck, 1974). 
The decay of the source plant matter and root respiration are the two primary sources of soil $\mathrm{CO}_{2}$. The decomposition of plant matter and root respiration minimally fractionate the carbon isotope values and produce $\mathrm{CO}_{2}$ that have $\delta^{13} \mathrm{C}$ values similar to those of the vegetation. ${ }^{12} \mathrm{CO}_{2}$ is preferentially diffused out of the soil into the atmosphere (Amundson et al., 1998; Cerling et al., 1991). This diffusion can cause the soil $\mathrm{CO}_{2}$ to be approximately $4-5 \%$ more enriched than that of the soil organic matter depending on respiration and diffusion rates (Boutton, 1991). The isotopic values of soil $\mathrm{CO}_{2}$ at the Marshall County site range from $-29.2 \%$ o to $-21.0 \%$ V-PDB. The observed variation in values of the $\delta^{13} \mathrm{C}_{\mathrm{CO} 2}$ of soil $\mathrm{CO}_{2}$ are comparable to seasonal isotopic variations of $-29 \%$ o to $-22 \%$ observed at similar sites in temperate climates with primarily C3 vegetation (Hesterberg and Siegenthaler, 1991). The isotopic variation is attributed to different rates of root respiration in different seasons. For example, a decrease in $\delta^{13} C_{\mathrm{CO} 2}$ in the early fall is hypothesized to be result of increased respiration of lighter ${ }^{12} \mathrm{C}$ compared to enriched $\delta^{13} \mathrm{C}_{\mathrm{CO} 2}$ values in the late spring .

A comparison of site specific $\delta^{13} \mathrm{C}$ values of the vegetation and soil $\mathrm{CO}_{2}$ samples collected in May 2014 indicate a varying enrichment factor at each site ranging from $2.2 \%$ o to $7.8 \%$ with an average enrichment of $4.5 \%$, which is within the range reported by the literature (Boutton, 1991). The processes that create soil $\mathrm{CO}_{2}$, the calculated enrichment factors that are associated with each process, and the resulting $\delta^{13} \mathrm{C}$ values of each sample from May 2014 are illustrated in Figure 8. If the vegetation with average isotope values of $-30.2 \%$ o degrades, produces $\mathrm{CO}_{2}$ and lighter $\mathrm{CO}_{2}$ diffuses out with the average calculated fractionation factor at this site of $+4.5 \%$, soil-respired $\mathrm{CO}_{2}$ would have a $\delta^{13} \mathrm{C}_{\mathrm{CO} 2}$ value of $-25.7 \%$, which is within the range reported from May 2014 on Figure 6, indicating that primary source of the soil $\mathrm{CO}_{2}$ is from the 
$\mathrm{C} 3$ vegetation of the area. If the injected $\mathrm{CO}_{2}$ were to leak from the Upper Freeport coal seam and infiltrate the shallow soil vadose zone, a shift from the vadose zone's natural range of $31.2 \%$ and $-25.6 \%$ o towards the isotope value of injected $\mathrm{CO}_{2}$ of approximately $-11.4 \%$ would occur. However, because the observed values of the $\delta^{13} \mathrm{C}_{\mathrm{CO} 2}$ of soil $\mathrm{CO}_{2}$ are comparable to previously recorded soil $\mathrm{CO}_{2}$ seasonal variation of other studies with primarily $\mathrm{C} 3$ vegetation and there is no significant change from the $\mathrm{CO}_{2}$ injection period (August 2013 through November 2013) to post-injection period (November 2013 to August 2014), we can conclude that there is no indication of significant leakage of $\mathrm{CO}_{2}$ from the Upper Freeport coal seam to the shallow soil.

\section{Groundwater Dissolved Inorganic Carbon (DIC)}

Two primary sources of DIC in groundwater are the dissolution of soil $\mathrm{CO}_{2}$ and limestone or dolomite dissolution (Clark and Fritz, 1997). However, since the Dunkard group, which the W-1, W-2 \& W-3 groundwater wells are sampling from at this site, are primarily composed of siliclastic rocks such as sandstones and shales, the primary source of DIC in the sampled groundwater is from $\mathrm{CO}_{2}$ soil gas dissolution.

At this site, the $\mathrm{pH}$ of the waters was consistently between 8.06 and 9.29 (Hega, 2013)(Hega, unpublished datapersonal communication, 2013). The temperature values of the groundwater wells were consistent over the time of sampling and the average temperature of groundwater was $12.6^{\circ} \mathrm{C}$. There are two primary reactions that fractionate the carbon isotopes as soil $\mathrm{CO}_{2}$ dissolves in groundwater to create DIC. These two fractionations occur when the $\mathrm{CO}_{2}$ gas diffuses into solution and then when $\mathrm{CO}_{2}(\mathrm{aq})$ disassociates into $\mathrm{HCO}_{3}-(\mathrm{aq})$. 
The $\delta^{13} \mathrm{CDIC}_{\mathrm{Da}}$ value of groundwater can be modeled from the concentrations of $\mathrm{CO}_{2}(\mathrm{aq}), \mathrm{HCO}_{3}^{-}$ and $\mathrm{CO}_{3}{ }^{2-}$ and equilibrium isotopic enrichment factors if it is assumed that the sole source of carbon is from the soil $\mathrm{CO}_{2}$ at the site (average $\delta^{13} \mathrm{C}=-25.0 \%$ ) and that a state of equilibrium exists in the system. The total DIC in the groundwater can be calculated by knowing the temperature, $\mathrm{pH}$ and Alkalinity (as mol/ $\mathrm{L} \mathrm{HCO}_{3}{ }^{-}$) and then using the Van't Hoff equation (1) and the equilibrium equations to calculate the concentration of each of the carbon species:

$$
\begin{aligned}
& \text { (1) } \log \mathrm{K}_{\mathrm{T} 2}=\log \mathrm{K}_{\mathrm{T} 1}+\left(\Delta \mathrm{H}_{\mathrm{R}}{ }^{0} / 2.303 \mathrm{R}\right)\left(1 / \mathrm{T}_{1}-1 / \mathrm{T}_{2}\right) \\
& \text { (2) }\left[\mathrm{H}_{2} \mathrm{CO}_{3}\right]=\left(\left[\mathrm{HCO}_{3}^{-}\right]^{*}\left[\mathrm{H}^{+}\right]\right) /\left(\mathrm{K}_{1}\right) \\
& \text { (3) }\left[\mathrm{CO}_{3}{ }^{2-}\right]=\left(\mathrm{K}_{2}{ }^{*}\left[\mathrm{HCO}_{3}^{-}\right]\right) /\left[\mathrm{H}^{+}\right] \\
& \text {(4) }[\text { Total DIC }]=\left[\mathrm{H}_{2} \mathrm{CO}_{3}\right]+\left[\mathrm{HCO}_{3}^{-}\right]+\left[\mathrm{CO}_{3}^{2-}\right]
\end{aligned}
$$

where $K_{1}$ and $K_{2}$ are calculated equilibrium constants (Drever, 1988) at temperatures $T_{1}$ and $T_{2}$ in Kelvin respectively, and then back calculating the concentrations of each species of carbon. When the data from the May 2014 sample collection at well W-2 with a temperature of $12.2^{\circ} \mathrm{C}$, $\mathrm{pH}$ of 8.46 , and the average alkalinity of $189 \mathrm{mg} / \mathrm{L}$, the concentration of species of carbon were found: $m \mathrm{H}_{2} \mathrm{CO}_{3}=2.85 \mathrm{E}-05 \mathrm{~mol} / \mathrm{L}, \mathrm{mHCO}_{3}{ }^{-}=0.0031 \mathrm{~mol} / \mathrm{L}$ and $m \mathrm{mCO}_{3}{ }^{2-}=3.29 \mathrm{E}-05 \mathrm{~mol} / \mathrm{L}$. The Total DIC concentration was $0.0032 \mathrm{~mol} / \mathrm{L}$. This indicates that the dominant carbon species in the groundwater of $\mathrm{W}-2$ is $\mathrm{HCO}_{3}$.

Once the concentration values of the carbon species have been calculated the following equation allows for the calculation of expected $\delta^{13} \mathrm{CDIC} \delta^{13} \mathrm{CDIC}_{(}\left(m \mathrm{CO}_{2 \text { (aq) }}+m \mathrm{HCO}_{3}{ }^{-}+m \mathrm{CO}_{3}{ }^{2-}\right)=$ $m \mathrm{CO}_{2 \text { (aq) }}\left(\delta^{13} \mathrm{C}_{\mathrm{CO} 2(\mathrm{~g})}+\varepsilon^{13} \mathrm{CCO}_{\mathrm{COaq}}-\mathrm{CO} 2(\mathrm{~g})\right)+m \mathrm{HCO}_{3}{ }^{-}\left(\delta^{13} \mathrm{CCO}_{\mathrm{CO}}(\mathrm{g})+\varepsilon^{13} \mathrm{C}_{\mathrm{HCO}-\mathrm{CO} 2(\mathrm{~g})}\right)+\mathrm{mCO}_{3}{ }^{2-}\left(\delta^{13} \mathrm{C}_{\mathrm{CO} 2(\mathrm{~g})}+\varepsilon\right.$ $\left.{ }^{13} \mathrm{C}_{\mathrm{CO}-\mathrm{CO}(\mathrm{g})}\right)$ where the concentrations of each species are in $\mathrm{mol} / \mathrm{L}$. The isotopic fractionation 
factors $(\varepsilon)$ used in this calculation were determined by Vogel et al. (1970), Mook et al. (1974), and Deines et al. (1974). These isotopic enrichment factors are temperature-dependent variables that were calculated from the equation $10^{3} \ln \alpha=a\left(10^{6} / T_{k}{ }^{2}\right)+b\left(10^{3} / T_{k}\right)+c$ where temperature $\left(T_{k}\right)$ is in degree Kelvin and $a, b$, and $c$ are constants. Using this model with a $\delta^{13} C$ soil $\mathrm{CO}_{2}$ value of $-25 \%$ and the measured groundwater temperature of $12.2^{\circ} \mathrm{C}$, the expected $\delta^{13} C_{D I C}$ for this site would be approximately $-15.7 \%$.

The measured $\delta^{13} C_{D I C}$ values ranged from $-18.2 \%$ to $-15.8 \%$ ond are comparable to the modeled value $(-15.7 \%$ ). Since the values are similar, it is reasonable to state that the sole source of the DIC in this water is from the soil $\mathrm{CO}_{2}$. If leakage were to occur from the Upper Freeport coal seam to the shallow groundwater and the source of DIC changed from the soil $\mathrm{CO}_{2}$ to injected $\mathrm{CO}_{2}$ a significant change in the value of $\delta^{13} \mathrm{C}_{\mathrm{DIC}}$ would be expected because of the difference in isotope values of the two gas sources, $-25.0 \%$ (soil) and $-11.4 \%$ (injected $\mathrm{CO}_{2}$ ) respectively. As the two sources mix, the $\delta^{13} C_{D I C}$ value would become increasingly more enriched. If injected $\mathrm{CO}_{2}$ was to leak into shallow groundwater and the same parameters $(\mathrm{pH}$, temperature and alkalinity) are used to model the $\delta^{13} C_{D I C}$ signature, the $\delta^{13} C_{D I C}$ value of the groundwater would be $-2.0 \%$.

The monthly $\delta^{13} C_{D I C}$ values for the three groundwater wells are shown in Figure 7. Samples could not be collected for 3 months, January-March 2014, as well sampling tubings were frozen. The $\delta^{13} C_{D I C}$ stayed consistent over the sampling period and shows no evidence of shifting towards more enriched values. Therefore, there is no indication of significant leakage from the Upper Freeport coal seam and it can be concluded that the source of the DIC in the groundwater is from the soil $\mathrm{CO}_{2}$. 


\subsection{Conclusions}

Samples collected from soil vadose gas wells, shallow groundwater wells and overlying Pittsburgh coal bed producing gas wells were used to monitor potential $\mathrm{CO}_{2}$ leakage from the underlying Upper Freeport coal seam in which $\mathrm{CO}_{2}$ was injected. Monitoring was carried out during the injection and the post injection monitoring period from August 2013 to August 2014. The natural variations in $\delta^{13} \mathrm{C}$ values of natural sources of $\mathrm{CO}_{2}$, i.e. vegetation, soil $\mathrm{CO}_{2}$ and DIC were modeled to decouple natural seasonal variations from changes expected due to leakage of $\mathrm{CO}_{2}$ from injected formation. The $\delta^{13} \mathrm{C}$ values of vegetation $(-31.2 \%$ o to $-26.5 \%$ ) collected in May 2014 indicate that the vegetation at the site is primarily C3 plants. The measured $\delta^{13} \mathrm{C}_{\mathrm{CO} 2}$ values of the soil vadose gas are within the expected range of soil $\mathrm{CO}_{2}$ produced from the decay of the $\mathrm{C} 3$ vegetation and subsequent enrichment due to diffusion of lighter ${ }^{12} \mathrm{CO}_{2}$.

The $\delta^{13} C_{\text {DIC }}$ values were modeled based on average DIC speciation, groundwater temperature, and diffusing soil gas as the $\mathrm{CO}_{2}$ source. The $\delta^{13} \mathrm{C}_{\mathrm{DIC}}$ calculated from the model $(-15.7 \%$ ) was comparable with the average $\delta^{13} C_{D I C}$ from the groundwater wells at the test site $(-16.5 \%$ o indicating that primary source of $\mathrm{DIC}$ is the soil vadose $\mathrm{CO}_{2}$ at the site. The overlying Pittsburgh coal seam has very enriched $\delta^{13} \mathrm{C}_{\mathrm{CO} 2}$ values (+19.1\%o to $+25.4 \%$ o) compared to injected $\mathrm{CO}_{2}$ ($11.4 \%$ ) and would change even if $1.5 \%$ of injected $\mathrm{CO}_{2}$ was to leak into this coal bed. However, the $\delta^{13} \mathrm{C}_{\mathrm{CO} 2}$ values remained consistently enriched throughout the monitoring period indicating no measured $\mathrm{CO}_{2}$ leakage had occurred from underlying Upper Freeport coal bed during this monitoring period.

The $\delta^{13} C_{\mathrm{CO} 2}$ and $\delta^{13} C_{D I C}$ values of the formations overlying the deep injection zone are within the expected ranges for natural sources for $\mathrm{CO}_{2}$ at the Marshall County site. The distinct 
differences between these natural values and the $\delta^{13} \mathrm{C}_{\mathrm{CO}}$ value of the $\mathrm{CO}_{2}$ that was injected into the Upper Freeport coal seam allowed use of carbon isotope signatures to track potential $\mathrm{CO}_{2}$ leakage at the site. The results indicate that during the sampling period there is no evidence of significant carbon dioxide leakage from the Upper Freeport to the shallow groundwater and soil vadose zones at this carbon sequestration test site.

\subsection{Acknowledgements}

This research was conducted as part of the National Energy Technology Laboratory's Regional University Alliance (NETL-RUA), a collaborative initiative of the NETL; this technical effort was performed under the RES contract DE-FE0004000. This project was supported by National Science Foundation's early career instrumentation grant (EAR-1205596) to S. Sharma. Dr. Richard Bajura from National Research Center for Coal and Energy (NRCCE) is also thanked for providing partial funding for this research. We would like to thank Dr. Henry Rauch, Brad Hega Stephen Henry, J. Rodney Diehl and Dennis Stanko for their invaluable help in setting up the wells at the site and coordinating their sampling efforts with ours. Special thanks to James E. Locke, CONSOL Energy Inc's manager of field testing and operations for his help and permission for field site access. Lastly, we would like to acknowledge students and technicians in the West Virginia Stable Isotope Laboratory for their field and lab support. 


\subsection{Conclusions}

Samples from soil vadose gas wells, shallow groundwater wells, and Pittsburgh coal bed producing gas wells were collected from August 2013 to August 2014 during the $\mathrm{CO}_{2}$ gas injection period and the post-injection monitoring periods at the ZERT/CONSOL Enhanced Coal Bed Methane and Carbon Sequestration site in Marshall County, WV. Sampling was done monthly to understand the natural $\delta^{13} \mathrm{C}$ values and sources of $\mathrm{CO}_{2}$ and $\mathrm{DIC}$ at the site. The natural variations in $\delta^{13} \mathrm{C}$ values of natural sources of $\mathrm{CO}_{2}$, i.e. vegetation, soil $\mathrm{CO}_{2}$ and $\mathrm{DIC}$ were modeled to decouple natural seasonal variations from changes expected due to leakage of $\mathrm{CO}_{2}$ from the Upper Freeport coal seam over the year of monitoring.

The Pittsburgh coal seam is the first overlying unit that would be affected by the leakage of the injected $\mathrm{CO}_{2}$ from the underlying Upper Freeport coal seam. The overlying Pittsburgh coal seam has very enriched $\delta^{13} \mathrm{C}_{\mathrm{CO} 2}$ values $\left(+19.1 \%\right.$ o to $+23.1 \%$ ) compared to injected $\mathrm{CO}_{2}(-11.4 \%$ ) and would change even if $1.5 \%$ of injected $\mathrm{CO}_{2}$ were to leak into the Pittsburgh coal seam. However, the $\delta^{13} \mathrm{C}_{\mathrm{CO} 2}$ values remained very consistent throughout the monitoring period indicating no detectable leakage had occurred from underlying Upper Freeport coal bed during this monitoring period. No isotopic shift was observed in Pittsburgh coal seam gas samples collected on $09 / 05 / 2013$, the day after an increased percentage of $\mathrm{CO}_{2}$ was recorded the Upper Freeport well MH-11 or at the end of sampling period on Aug 2014 when isotopic values clearly support that the plume of injected $\mathrm{CO}_{2}$ in the underlying Upper Freeport coal seam had travelled half of the study site width to reach the downstream monitoring well $\mathrm{MH}-11$. 
The $\delta^{13} \mathrm{C}$ values of vegetation collected in May 2014 indicate that the vegetation at the site is primarily $\mathrm{C} 3$ plants. The measured $\delta^{13} \mathrm{C}_{\mathrm{CO} 2}$ values of the soil vadose gas are within the expected range of soil $\mathrm{CO}_{2}$ produced from the decay of $\mathrm{C} 3$ vegetation and diffusion of lighter ${ }^{12} \mathrm{C}$. This indicates the source of the $\mathrm{CO}_{2}$ is the natural vegetation at the site. An isotopic fractionation and DIC concentration model for groundwater based on average DIC speciation, groundwater temperature and soil gas, was used to calculate $\delta^{13} C_{D I C}$ values. The $\delta^{13} C_{D I C}$ calculated from the model (-15.7\%) was comparable with the average $\delta^{13} \mathrm{C}_{\mathrm{DIC}}$ from the groundwater wells at the test site $\left(-16.5 \%\right.$ ) indicating that the primary source of DIC is the soil vadose $\mathrm{CO}_{2}$ at the site. The $\delta^{13} C_{\mathrm{CO} 2}$ and $\delta^{13} C_{D I C}$ values of the overlying formations at the Marshall County carbon sequestration site are within the ranges for natural sources for $\mathrm{CO}_{2}$ and within the limits of expected seasonal variation. The distinct differences between these natural values and the $\delta^{13} C_{\mathrm{CO} 2}$ value of the $\mathrm{CO}_{2}$ that was injected into the Upper Freeport coal seam allowed for stable carbon isotopes to be excellent natural tracers of $\mathrm{CO}_{2}$ leakage. However, $\delta^{13} \mathrm{Cvalues}$ of all the gas and water samples collected at this site indicate that there is no evidence of significant leakage from the Upper Freeport coal bed to the overlying Pittsburgh coal bed, shallow groundwater, or soil vadose zone during the time of monitoring. 


\subsection{Figures}
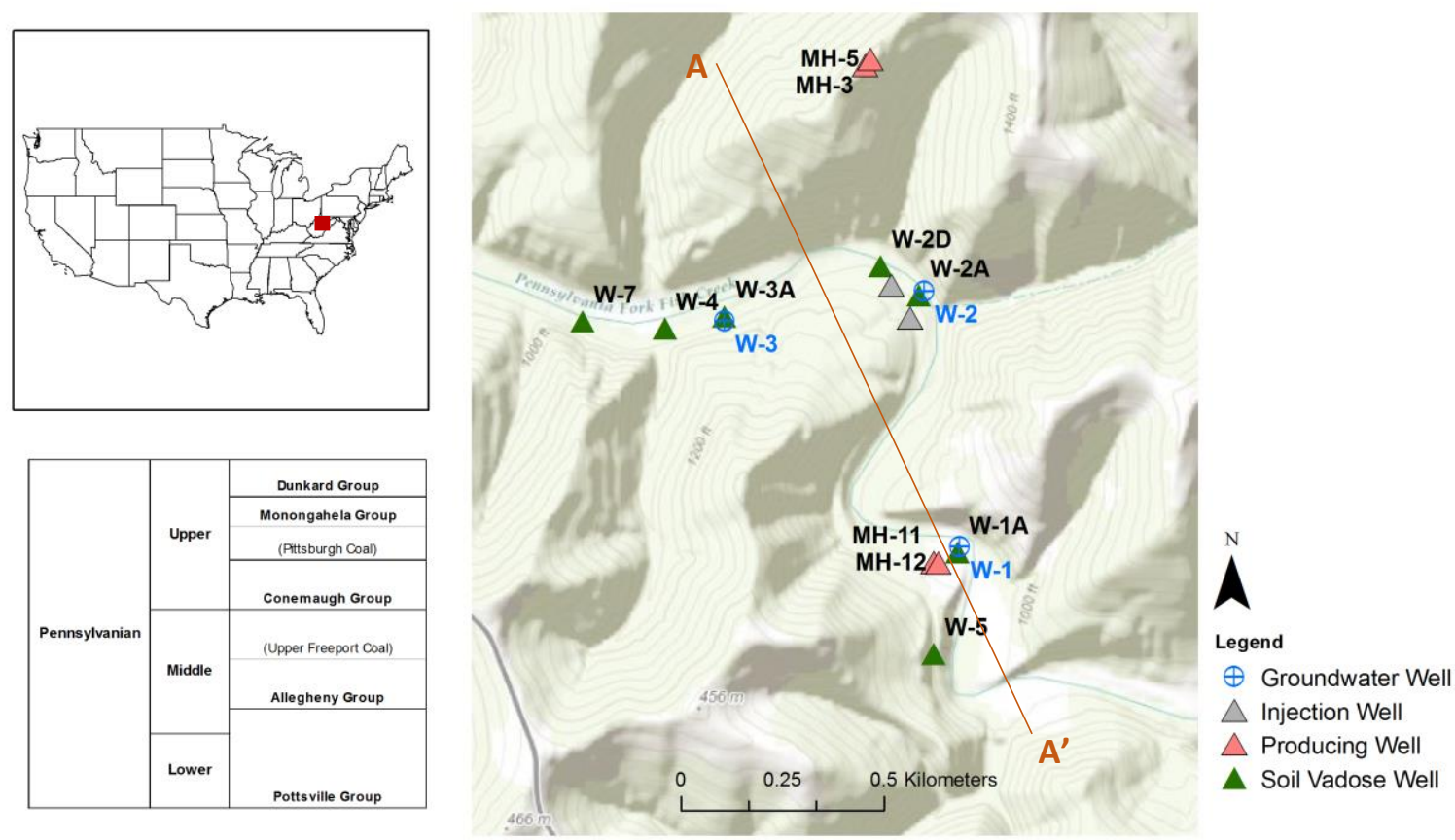

Figure 1. Location of the CONSOL Energy Carbon Sequestration Pilot Test Site in Marshall County, WV and geologic strip log of the site. Line $A-A^{\prime}$ is the line of reference for the cross section depicted in

Figure 3

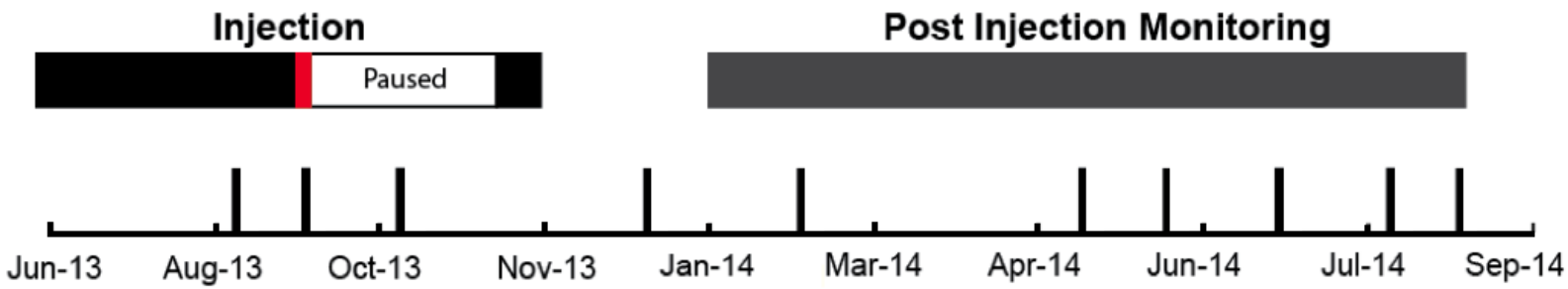

Figure 2. Timeline of the isotope sample collection at the Marshall County Site from August 20132014. The dark horizontal bars were times of active injection. The grey bar indicates the post-injection monitoring period. The tall vertical lines are dates of sampling for this study. The red line is $09 / 2013$ when a high $\mathrm{CO}_{2} \%$ was recorded at a downstream Upper Freeport producing well, MH-11. 


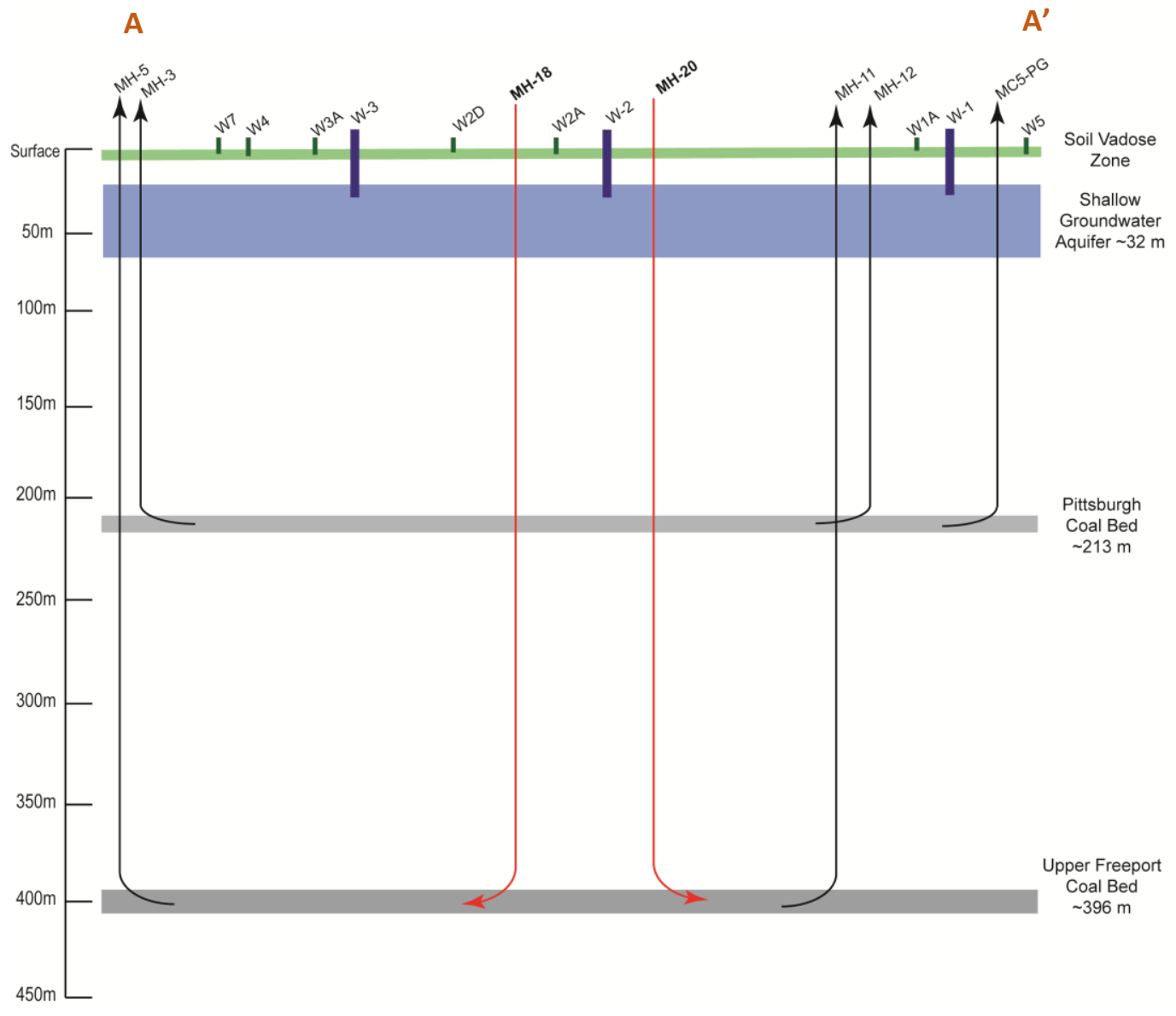

Figure 3. Schematic cross sectional view of the Marshall County, WV site showing relative depths of both coal seams, shallow groundwater wells and soil vadose wells. The red wells in the center are $\mathrm{CO}_{2}$ Injection wells. This cross section is relative to the line A-A' in Figure 1.

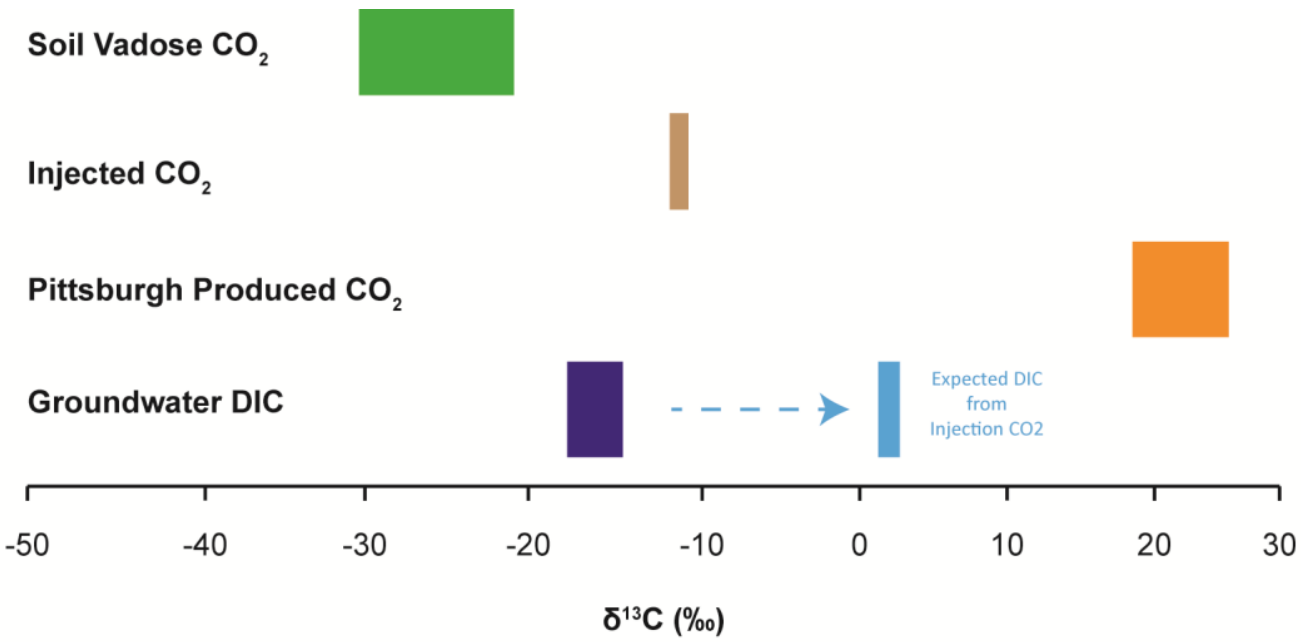

Figure 4. Comparison of the $\delta^{13} \mathrm{C}_{\mathrm{CO} 2}$ values of the distinct isotopic end members of the Marshall County site 


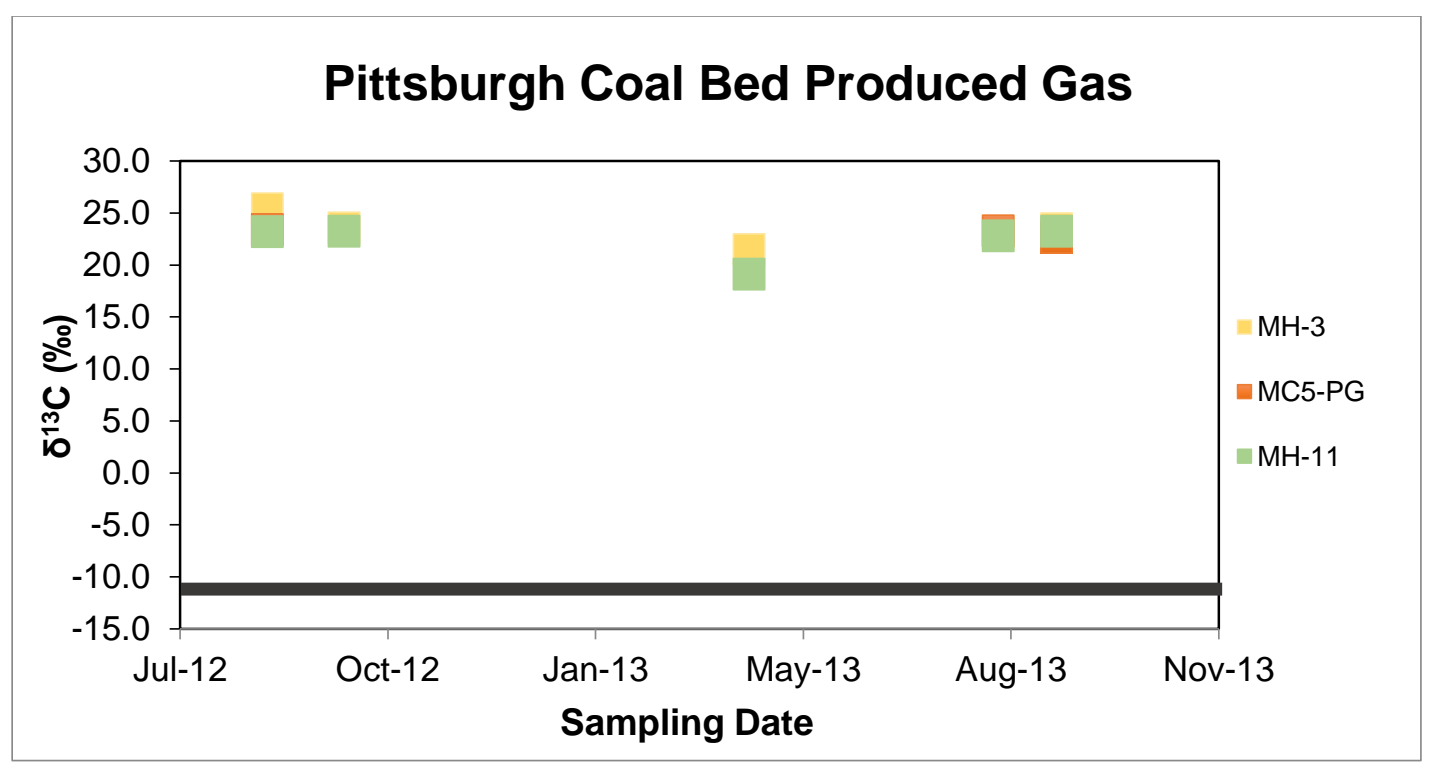

Figure 5. Monthly $\delta^{13} \mathrm{C}_{\mathrm{CO} 2}$ values of produced gas during the scheduled period of $\mathrm{CO}_{2}$ injection. The dark grey line indicates the $\delta^{13} \mathrm{C}_{\mathrm{CO} 2}$ of the injected $\mathrm{CO}_{2}$.

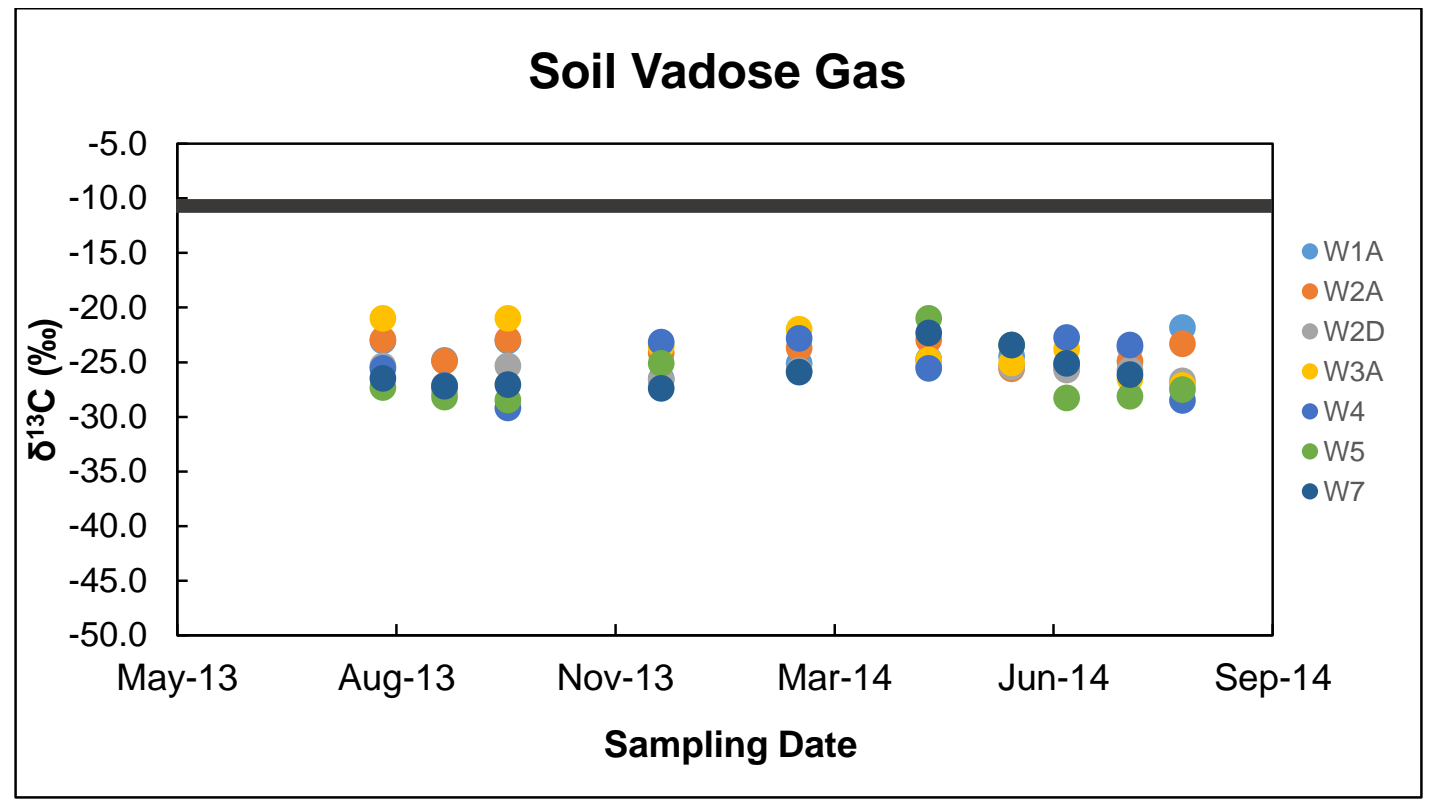

Figure 6. Monthly $\delta^{13} \mathrm{C}_{\mathrm{CO} 2}$ of soil vadose gas during the August 2013 to August 2014 sampling period. The dark grey line indicates the $\delta^{13} \mathrm{C}_{\mathrm{CO} 2}$ of the injected $\mathrm{CO}_{2}$. 


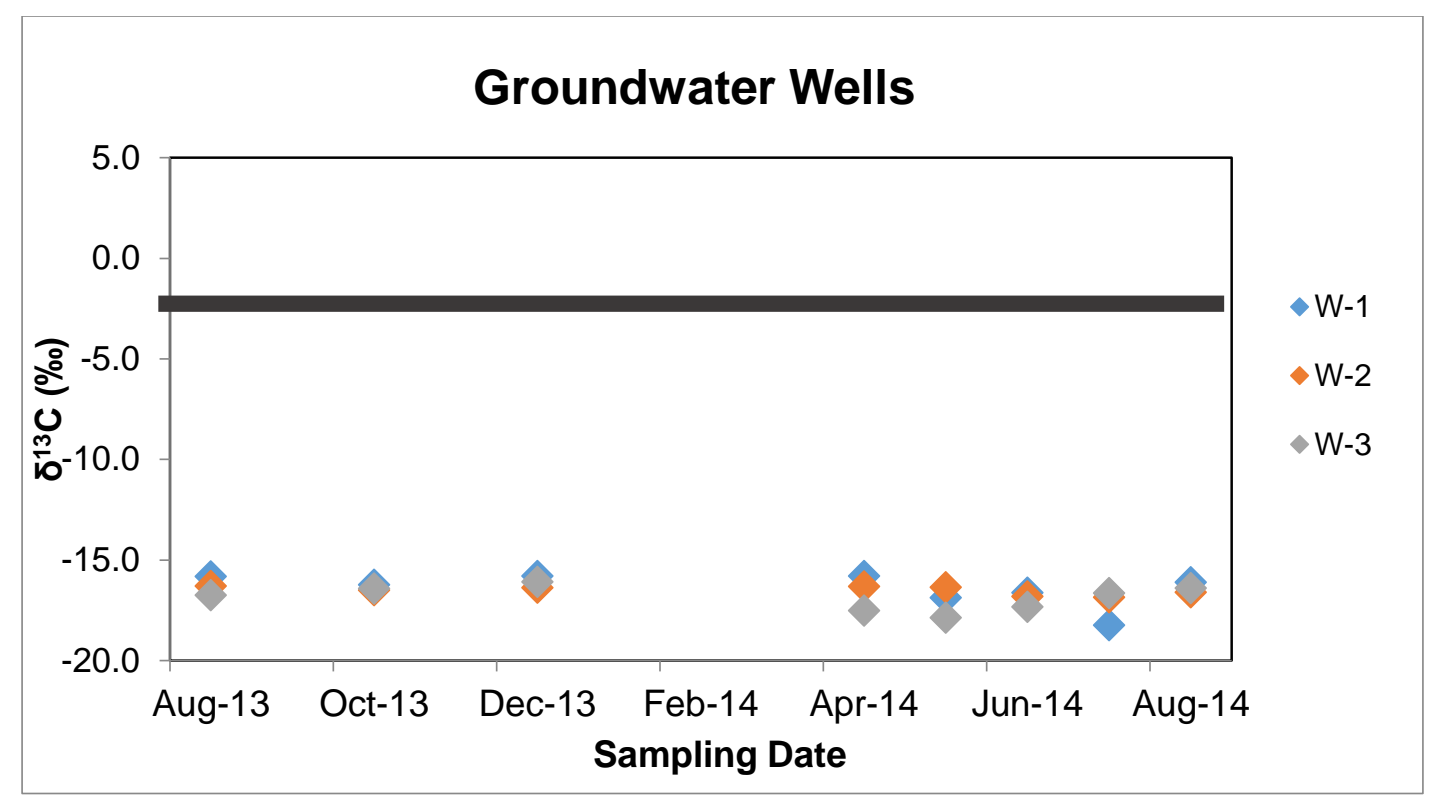

Figure 7. Monthly $\delta^{13} C_{D I C}$ values of groundwater during the August 2013 to August 2014 sampling period. The red line indicates the $\delta^{13} C_{D I C}$ of the groundwater if the injected $\mathrm{CO}_{2}$ became the primary source of DIC. Groundwater samples were unable to be collected during January to March 2014 due to frozen wells.

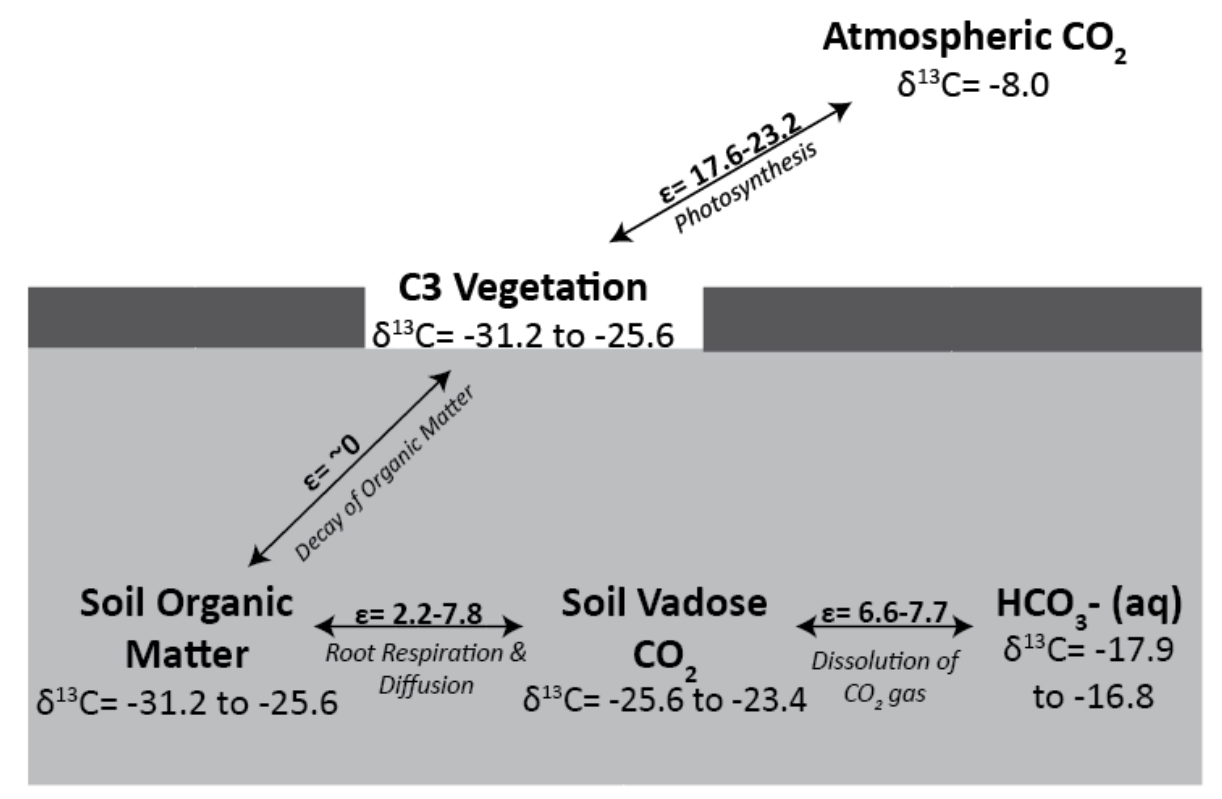

Figure 8. Schematic of the $\delta^{13} \mathrm{C}$ values of different carbon sources, fractionation processes, and the expected enrichment factors that affect the carbon isotope signatures of different end-members at the study site. 


\subsection{Tables}

\begin{tabular}{|c|c|c|c|}
\hline Sample ID & $\begin{array}{c}\text { Average } \delta^{13} \mathrm{C} \\
(\%)\end{array}$ & $\underset{(\%)}{\operatorname{Minimum}} \delta^{13} \mathrm{C}$ & $\underset{(\% o)}{\operatorname{Maximum}} \delta^{13} \mathrm{C}$ \\
\hline \multicolumn{4}{|l|}{ Injection $\mathrm{CO}_{2}$} \\
\hline & $\begin{array}{c}-11.6 \\
n=3\end{array}$ & $\begin{array}{c}-12.1 \\
n=3\end{array}$ & $\begin{array}{c}-11.0 \\
n=3\end{array}$ \\
\hline \multicolumn{4}{|c|}{ Groundwater DIC } \\
\hline W-1 & $\begin{array}{c}-16.4 \\
n=8\end{array}$ & $\begin{array}{c}-18.2 \\
n=8\end{array}$ & $\begin{array}{c}-15.8 \\
n=8\end{array}$ \\
\hline W-2 & $\begin{array}{c}-16.6 \\
n=7\end{array}$ & $\begin{array}{c}-16.9 \\
n=7\end{array}$ & $\begin{array}{c}-16.3 \\
n=7\end{array}$ \\
\hline W-3 & $\begin{array}{c}-16.8 \\
n=7\end{array}$ & $\begin{array}{c}-17.9 \\
n=7\end{array}$ & $\begin{array}{c}-16.1 \\
n=7\end{array}$ \\
\hline \multicolumn{4}{|c|}{ Soil Vadose $\mathrm{CO}_{2}$} \\
\hline W1A & $\begin{array}{c}-24.2 \\
n=10\end{array}$ & $\begin{array}{c}-26.5 \\
n=10\end{array}$ & $\begin{array}{c}-21.8 \\
n=10 \\
\end{array}$ \\
\hline W2A & $\begin{array}{c}-24.1 \\
n=10\end{array}$ & $\begin{array}{c}-25.6 \\
n=10\end{array}$ & $\begin{array}{c}-22.9 \\
n=10\end{array}$ \\
\hline W2D & $\begin{array}{c}-25.9 \\
n=10\end{array}$ & $\begin{array}{c}-27.5 \\
n=10\end{array}$ & $\begin{array}{c}-25.3 \\
n=10\end{array}$ \\
\hline W3A & $\begin{array}{c}-24.3 \\
n=10\end{array}$ & $\begin{array}{c}-27.8 \\
n=10\end{array}$ & $\begin{array}{c}-21.0 \\
n=10\end{array}$ \\
\hline W4 & $\begin{array}{c}-25.3 \\
n=7\end{array}$ & $\begin{array}{c}-29.2 \\
n=7\end{array}$ & $\begin{array}{c}-22.7 \\
n=7\end{array}$ \\
\hline W5 & $\begin{array}{c}-26.4 \\
n=9\end{array}$ & $\begin{array}{c}-28.5 \\
n=9\end{array}$ & $\begin{array}{c}-21.0 \\
n=9\end{array}$ \\
\hline W7 & $\begin{array}{c}-25.4 \\
n=9\end{array}$ & $\begin{array}{c}-27.4 \\
n=9\end{array}$ & $\begin{array}{c}-22.3 \\
n=9\end{array}$ \\
\hline \multicolumn{4}{|c|}{ Produced Gas $\mathrm{CO}_{2}$} \\
\hline MH-3 (P) & $\begin{array}{c}23.1 \\
n=6\end{array}$ & $\begin{array}{c}21.1 \\
\mathrm{n}=6\end{array}$ & $\begin{array}{c}25.4 \\
n=6\end{array}$ \\
\hline MC5-PG (P) & $\begin{array}{c}23.1 \\
n=4\end{array}$ & $\begin{array}{c}22.7 \\
n=4\end{array}$ & $\begin{array}{c}23.5 \\
n=4\end{array}$ \\
\hline MH-12 (P) & $\begin{array}{c}22.3 \\
n=6\end{array}$ & $\begin{array}{c}19.1 \\
n=6\end{array}$ & $\begin{array}{c}23.3 \\
n=6\end{array}$ \\
\hline
\end{tabular}

Table 1. A comparison of average $\delta^{13} \mathrm{C}$ values of the produced Pittsburgh CO2, shallow groundwater and soil vadose gas samples collected. 


\begin{tabular}{|c|c|c|}
\cline { 2 - 3 } \multicolumn{1}{c|}{} & \multicolumn{2}{c|}{ Averages } \\
\cline { 2 - 3 } \multicolumn{1}{c|}{} & $\boldsymbol{\delta}^{13} \mathrm{C}_{\mathrm{CH} 4}(\%)$ & $\delta_{\mathrm{CH} 4}(\%)$ \\
\hline \multicolumn{2}{c|}{ Pittsburgh Coal Seam } & $\begin{array}{c}-192.1 \pm 1.9 \\
\mathrm{n}=3\end{array}$ \\
\hline MH-3 & $\begin{array}{c}-47.8 \pm 0.2 \\
\mathrm{n}=3\end{array}$ & $\begin{array}{c}196.2 \pm 0.9 \\
\mathrm{n}=3\end{array}$ \\
\hline MC5-PG & $\begin{array}{c}-48.7 \pm 0.1 \\
\mathrm{n}=3\end{array}$ & $\begin{array}{c}-195.1 \pm 0.2 \\
\mathrm{n}=4\end{array}$ \\
\hline MH-12 & $\begin{array}{c}-48.0 \pm 0.1 \\
\mathrm{n}=4\end{array}$ & \\
\hline Upper Freeport Coal Seam & $\begin{array}{c}-176.2 \pm 1.0 \\
\mathrm{n}=2\end{array}$ \\
\hline MH-5 & $-\begin{array}{c}-43.1 \pm 0.1 \\
\mathrm{n}=2\end{array}$ & $\begin{array}{c}-175.8 \pm 1.3 \\
\mathrm{n}=4\end{array}$ \\
\hline MH-11 & $\begin{array}{c}-43.1 \pm 0.6 \\
\mathrm{n}=4\end{array}$ & \\
\hline
\end{tabular}

Table 2. A summary of the $\delta^{13} \mathrm{C}_{\mathrm{CH} 4}$ and the $\delta \mathrm{D}_{\mathrm{CH} 4}$ of the Pittsburgh and Upper Freeport coal seam produced natural gas collected during the injection of $\mathrm{CO}_{2}$

\begin{tabular}{|c|c|}
\hline Sample ID & $\mathbf{\delta}^{\mathbf{1 3}} \mathbf{C}(\%)$ \\
\hline \multicolumn{2}{|c|}{ Vegetation } \\
\hline W1A & -28.8 \\
\hline W2A & -30.6 \\
\hline W2D & -30.0 \\
\hline W3 & -28.4 \\
\hline W4 & -17.0 \\
\hline W5 & -31.2 \\
\hline W7 & -25.6 \\
\hline
\end{tabular}

Table 3. Summary of the $\delta^{13} \mathrm{C}$ values of the vegetation collected in May of 2014. 


\subsection{References}

Amundson, R., Stern, L., Baisden, T., and Wang, Y., 1998, The isotopic composition of soil and soil-respired CO2: Geoderma, v. 82, no. 1, p. 83-114.

Atlas, N. A. C. S., 2013, NACSA- The North American Carbon Storage Atlas, in (NACAP), N. A. C. A. P., ed., Volume 2013.

Boutton, T. W., 1991, Stable carbon isotope ratios of natural materials: II. Atmospheric, terrestrial, marine, and freshwater environments: Carbon isotope techniques, v. 1, p. 173.

Cerling, T. E., Solomon, D. K., Quade, J., and Bowman, J. R., 1991, On the isotopic composition of carbon in soil carbon dioxide: Geochimica et Cosmochimica Acta, v. 55, no. 11, p. 3403-3405.

Clark, I. D., and Fritz, P., 1997, Environmental Isotopes in Hydrogeology, Boca Raton, Lewis Publishers.

Clayton, J., 1998, Geochemistry of Coalbed Gas-A Review: International Journal of Coal Geology, v. 35, no. 1, p. 159-173.

Drever, J., 1988, The Geochemistry of Natural Waters, Prentice-Hall, Englewood Cliffs, NJ.

Emberley, S., Hutcheon, I., Shevalier, M., Durocher, K., Gunter, W., and Perkins, E., 2004, Geochemical monitoring of fluid-rock interaction and $\mathrm{CO} 2$ storage at the Weyburn CO2injection enhanced oil recovery site, Saskatchewan, Canada: Energy, v. 29, no. 9, p. 1393-1401.

Emberley, S., Hutcheon, I., Shevalier, M., Durocher, K., Mayer, B., Gunter, W., and Perkins, E., 2005, Monitoring of fluid-rock interaction and CO2 storage through produced fluid sampling at the Weyburn CO2-injection enhanced oil recovery site, Saskatchewan, Canada: Applied Geochemistry, v. 20, no. 6, p. 1131-1157.

Farquhar, G. D., Ehleringer, J. R., and Hubick, K. T., 1989, Carbon isotope discrimination and photosynthesis: Annual review of plant biology, v. 40, no. 1, p. 503-537.

Farquhar, G. D., O'leary, M., and Berry, J., 1982, On the relationship between carbon isotope discrimination and the intercellular carbon dioxide concentration in leaves: Functional Plant Biology, v. 9, no. 2, p. 121-137.

Fessenden, J., Clegg, S., Rahn, T., Humphries, S., and Baldridge, W., 2010, Novel MVA tools to track CO2 seepage, tested at the ZERT controlled release site in Bozeman, MT: Environmental Earth Sciences, v. 60, no. 2, p. 325-334.

Gale, J., and Freund, P., 2001, Coal-Bed Methane Enhancement with CO2 Sequestration Worldwide Potential: Environmental Geosciences, v. 8, no. 3, p. 210-217.

Geonet, $\mathrm{C} ., 2008$, What does $\mathrm{CO}_{2}$ geologic storage really mean?

Hega, B. D., 2013: Morgantown, WV, West Virginia University.

Hega, B. D., Berry, K. E., and Rauch, H., The Environmental Effects of Geologically Sequestered Carbon Dioxide Gas and the Enhanced Recovery of Coal Bed Methane from an Unmineable Coal Seam, in Proceedings Geological Society of America Annual Meeting, Minneapolis, MN, USA, 2011.

Hesterberg, R., and Siegenthaler, U., 1991, Production and stable isotopic composition of CO2 in a soil near Bern, Switzerland: Tellus B, v. 43, no. 2, p. 197-205. 
Johnson, G., Mayer, B., Shevalier, M., Nightingale, M., and Hutcheon, I., 2011, Tracing the movement of $\mathrm{CO} 2$ injected into a mature oilfield using carbon isotope abundance ratios: The example of the Pembina Cardium CO2 Monitoring project: International Journal of Greenhouse Gas Control, v. 5, no. 4, p. 933-941.

Johnson, G., Raistrick, M., Mayer, B., Shevalier, M., Taylor, S., Nightingale, M., and Hutcheon, I., 2009, The use of stable isotope measurements for monitoring and verification of $\mathrm{CO} 2$ storage: Energy Procedia, v. 1, no. 1, p. 2315-2322.

Keeling, C. D., Mook, W. G., and Tans, P. P., 1979, Recent trends in the $13 \mathrm{C} / 12 \mathrm{C}$ ratio of atmospheric carbon dioxide: Nature, v. 277, p. 121-123.

Kharaka, Y., Cole, D., Hovorka, S., Gunter, W., Knauss, K., and Freifeld, B., 2006, Gas-water-rock interactions in Frio Formation following $\mathrm{CO} 2$ injection: Implications for the storage of greenhouse gases in sedimentary basins: Geology, v. 34, no. 7, p. 577-580.

Kharaka, Y. K., Thordsen, J. J., Kakouros, E., Ambats, G., Herkelrath, W. N., Beers, S. R., Birkholzer, J. T., Apps, J. A., Spycher, N. F., and Zheng, L., 2010, Changes in the chemistry of shallow groundwater related to the 2008 injection of $\mathrm{CO} 2$ at the ZERT field site, Bozeman, Montana: Environmental Earth Sciences, v. 60, no. 2, p. 273-284.

Locke, J. E., Winschel, R. A., Wilson, T. H., Siriwardane, H., Rauch, H., and Monaghegh, S. D., CO2 Sequestration in Unminable Coal with Enhanced Coal Bed Methane Recovery: The Marshall County Project, in Proceedings International Pittsburgh Coal Conference, Pittsburgh, PA, USA, 2011.

Lowdon, J., and Dyck, W., 1974, Seasonal variations in the isotope ratios of carbon in maple leaves and other plants: Canadian Journal of Earth Sciences, v. 11, no. 1, p. 79-88.

Mazzotti, M., Pini, R., and Storti, G., 2009, Enhanced coalbed methane recovery: The Journal of Supercritical Fluids, v. 47, no. 3, p. 619-627.

Mook, W. G., Bommerson, J. C., and Staverman, W. H., 1974, Carbon isotope fractionation between dissolved bicarbonate and gaseous carbon dioxide: Earth and Planetary Science Letters, v. 22, no. 2, p. 169-176.

Mook, W. G., and de Vries, J. J., 2001, Environmental Isotopes in the Hydrogeological Cycle: Principles and Application, Volume I: Introduction, Theory, Methods, Review, Vienna, Austria and Paris, France.

Mook, W. G., Koopmans, M., Carter, A. F., and Keeling, C. D., 1983, Seasonal, latitudinal, and secular variations in the abundance and isotopic ratios of atmospheric carbon dioxide: 1. Results from land stations: Journal of Geophysical Research: Oceans (1978-2012), v. 88, no. C15, p. 10915-10933.

Peter, A., Lamert, H., Beyer, M., Hornbruch, G., Heinrich, B., Schulz, A., Geistlinger, H., Schreiber, B., Dietrich, P., and Werban, U., 2012, Investigation of the geochemical impact of $\mathrm{CO} 2$ on shallow groundwater: design and implementation of a $\mathrm{CO} 2$ injection test in Northeast Germany: Environmental Earth Sciences, v. 67, no. 2, p. 335-349.

Raistrick, M., Mayer, B., Shevalier, M., Perez, R. J., Hutcheon, I., Perkins, E., and Gunter, B., 2006, Using chemical and isotopic data to quantify ionic trapping of injected carbon dioxide in oil field brines: Environmental science \& technology, v. 40, no. 21, p. 67446749.

Rauch, H., Hega, B. D., Felton, K., Bajura, R. A., Wilson, T. H., Locke, J. E., Winschel, R. A., Wells, A. W., and Diehl, J. R., 2012, Environmental Monitoring for CO2 Gas Sequestred in 
Underground Coal Associated with the CONSOL Energy Research Project, Marshall County, WV, USA, International Pittsburgh Coal Conference: Pittsburgh, PA, USA.

Rice, D. D., 1993, Composition and origins of coalbed gas: Hydrocarbons from coal: AAPG Studies in Geology, v. 38, p. 159-184.

Ruppert, L., and Rice, C., 2001, Chap. B-coal resource assessment methodology and geology of the northern and central Appalachian Basin coal regions, Northern and Central Appalachian Basin Coal Regions Assessment Team, 2000 Resource Assessment of Selected Coal Beds and Zones in the Northern and Central Appalachian Basin Coal Regions: US Geological Survey Professional Paper 1625-C.

Ruppert, L. F., Kirschbaum, M. A., Warwick, P. D., Flores, R. M., Affolter, R. H., and Hatch, J. R., 2002, The US Geological Survey's national coal resource assessment: the results: International Journal of Coal Geology, v. 50, no. 1, p. 247-274.

Schoell, M., 1980, The hydrogen and carbon isotopic composition of methane from natural gases of various origins: Geochimica et Cosmochimica Acta, v. 44, no. 5, p. 649-661.

Schulz, A., Vogt, C., Lamert, H., Peter, A., Heinrich, B., Dahmke, A., and Richnow, H.-H., 2012, Monitoring of a Simulated CO2 Leakage in a Shallow Aquifer Using Stable Carbon Isotopes: Environmental Science \& Technology, v. 46, no. 20, p. 11243-11250.

Vogel, J., 1993, Variability of Carbon Isotope Fractionation during Photosynthesis, Stable Isotopes and Plant Carbon-Water Relations: New York, NY, USA, Academic Press, p. 2946.

Vogel, J., Grootes, P., and Mook, W., 1970, Isotopic fractionation between gaseous and dissolved carbon dioxide: Zeitschrift für Physik, v. 230, no. 3, p. 225-238.

White, C. M., Smith, D. H., Jones, K. L., Goodman, A. L., Jikich, S. A., LaCount, R. B., DuBose, S. B., Ozdemir, E., Morsi, B. I., and Schroeder, K. T., 2005, Sequestration of Carbon Dioxide in Coal with Enhanced Coalbed Methane Recovery--A Review: Energy \& Fuels, v. 19, no. 3, p. 66.

Whiticar, M. J., 1999, Carbon and hydrogen isotope systematics of bacterial formation and oxidation of methane: Chemical Geology, v. 161, no. 1, p. 291-314.

Whiticar, M. J., Faber, E., and Schoell, M., 1986, Biogenic methane formation in marine and freshwater environments: $\mathrm{CO} 2$ reduction vs. acetate fermentation-Isotope evidence: Geochimica et Cosmochimica Acta, v. 50, no. 5, p. 693-709.

Wilson, T. H., Bajura, R. A., Winschel, R. A., Srivastiva, R. S., Scandrol, R., Wells, A. W., and Patchen, D. G., Geophysical characterization of the Marshall County West Virginia Pilot Sequestration Site, in Proceedings International Pittsburgh Coal Conference, Pittsburgh, PA, USA, 2009, p. 12.

Winschel, R. A., Locke, J. E., Srivastiva, R. S., Bajura, R. A., Wilson, T. H., Siriwardane, H., Rauch, H., Patchen, D. G., Hega, B. D., Gondle, R. K., and Wells, A. W., 2010, CO2 Sequestration in unminable coal with enhanced coal bed methane recovery: the Marshall County Project: Proceedings of the 2010 International Pittsburgh Coal Conference, Istanbul, Turkey, October 11-14, p. 15. 